\title{
Scientific rationale for traditional use of plants to treat tuberculosis in the eastern region of the OR Tambo district, South Africa
}

\author{
Madikizela, B., McGaw, L.J.* \\ Phytomedicine Programme, Department of Paraclinical Sciences, University of Pretoria, Private Bag X04, \\ Onderstepoort, 0110 Pretoria, South Africa
}

*Corresponding author

Lyndy McGaw: lyndy.mcgaw@up.ac.za

\begin{abstract}
Ethnopharmacological relevance: Tuberculosis (TB) remains a major health problem for humans worldwide, and was responsible for 1.4 million human deaths in 2015 alone. Although there is treatment for TB, emerging multi-drug, extensively drug and totally drug resistant forms of this disease, as well as co-infection with human immunodefiency virus (HIV) continue to worsen the situation. South Africa is among countries with reported traditional use and published documentation of such knowledge concerning the use of plants against TB. Based on a previous study where plants used traditionally for treating TB in the eastern region of OR Tambo district, South Africa, were documented, the present study aimed to determine the antimycobacterial effect, cytotoxicity and genotoxicity of plants selected from that list.
\end{abstract}

Material and methods: Acetone, 70\% ethanol, cold and hot water extracts were tested for antimycobacterial activity against saprophytic Mycobacterium species including $M$. aurum, $M$. bovis BCG, M. gordonae, $M$. fortuitum, and $M$. smegmatis using a microdilution method. Extracts with MIC values less than $1 \mathrm{mg} / \mathrm{ml}$ against at least three Mycobacterium strains were evaluated for antimycobacterial activity against pathogenic Mycobacterium strains including M. tuberculosis H37RV, M. tuberculosis and M. bovis, cytotoxicity (against Vero monkey kidney and bovine dermis cells), and genotoxicity (against Salmonella typhimurium TA98 and TA100).

Results: The MIC values of the extracts ranged from $0.02-2.50 \mathrm{mg} / \mathrm{ml}, \mathrm{LC}_{50}$ values of twentynine extracts ranged from $0.001->1 \mathrm{mg} / \mathrm{ml}$ and the highest selectivity index was 79.50 , an 
extremely promising value. Phymaspermum acerosum roots and leaves (ethanol and water) extracts had the best MIC value $(0.02 \mathrm{mg} / \mathrm{ml})$ against at least one Mycobacterium strain. It was interesting to note the lack of cytotoxicity of these extracts with the highest selectivity index value of 39.75. Pterocelastrus echinatus bark acetone and Protorhus longifolia leaf hot water extracts were the most cytotoxic with $\mathrm{LC}_{50}=0.001$ and $0.008 \mathrm{mg} / \mathrm{ml}$, respectively, whereas Pittosporum viridiflorum bark water extract was genotoxic. Among non-pathogenic strains, M. gordonae, M. aurum, M. smegmatis showed good correlation of activity with pathogenic M. tuberculosis H37Rv, M. tuberculosis and M. bovis, however, M. aurum was the best predictor with Mycobacterium tuberculosis H37Rv (correlation coefficient value $=0.73$ )

Conclusion: The results indicate that Heteromorpha trifoliata and Phymaspermum acerosum should be investigated further for antimycobacterial efficacy against drug resistant strains of Mycobacterium.

\section{Graphical abstract}

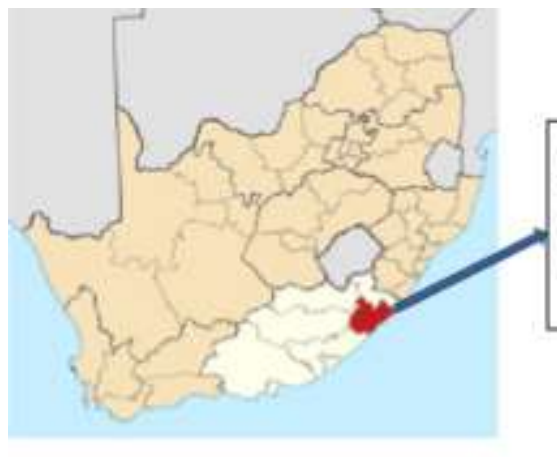

Eastern region of $O R$ Tambo district (in red), South Africa

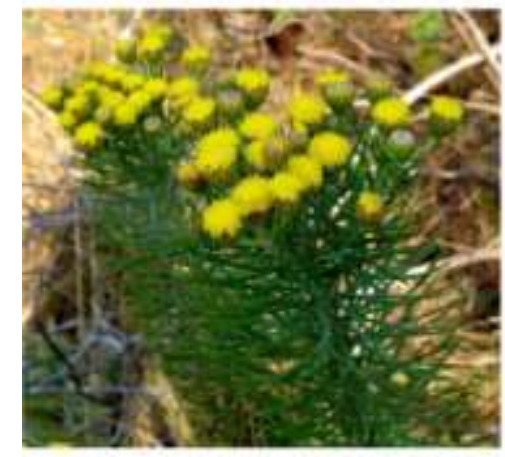

Phymaspermum acerosum
Plants used traditionally to treat tuberculosis: tested for activity against pathogenic and nonpathogenic Mycobacteriumspecies and for cytotoxicity and genotoxicity

Several extracts had promising antimycobacterial activity (MIC $=0.02 \mathrm{mg} / \mathrm{ml}$ ) and low cytotoxicity with selectivity values as high as 79.50. M. aurum was the best predictor of activity against $M$. tuberculosis $337 \mathrm{Rv}$

Keywords: Antimycobacterial, OR Tambo district, Phymaspermum acerosum, Heteromorpha trifoliata, safety evaluation, cytotoxicity 


\section{Introduction}

Tuberculosis (TB), an old yet re-emerging bacterial infectious disease, is one of the leading ten causes of mortality and morbidity worldwide infecting both humans and animals (cattle, and several other domestic and wild animals) (Fyhrquist et al., 2014; WHO, 2017). This disease is highly contagious, transmitted from one individual to another via droplet nuclei from a person with an active TB infection. TB is caused by organisms belonging to the Mycobacterium tuberculosis complex which includes $M$. africanum, M. bovis, the attenuated M. bovis Bacille Calmette-Guerin (BCG) vaccine strain, M. canetti, M. caprae, M. microti, M. pinnipedii, and M. mungi. There is treatment for TB, but it has limitations. The treatment protocol for TB is lengthy (6 months or longer for more resistant strains), the drugs have side effects, and poor compliance of patients infected with this disease has led to development of multi drug resistant (MDR), extensively drug resistant (XDR) and totally drug resistant (TDR) TB strains. Additionally, the association of TB with human immunodefiency virus (HIV) has worsened the complication of TB therapy. In 2015, there were an estimated 10.4 million new cases of TB worldwide, and people living with HIV accounted for 1.2 million of these (WHO, 2017). South Africa is among six countries accounting for $60 \%$ of new TB cases in 2015 (WHO, 2017). The number of TB deaths fell by $22 \%$ between 2000 and 2015; however, the disease still claimed approximately 1.4 million lives in 2015 alone, and 0.4 million were HIV positive people (WHO, 2017).

Many efforts have been made worldwide to discover and develop new anti-TB drugs that are superior to those available today in terms of their bactericidal activity, efficacy against drug resistant TB strains, safety tolerability, and suitability for coadministration with antiretroviral drugs (ARVs). Four compounds, namely moxifloxacin, gatifloxacin, bedaquiline, and delamanid have been discovered by the current global TB drug development programme, and these are still under evaluation for phase III clinical trials (Mdluli et al., 2015). Although bedaquiline or sirturo was approved by the United States Food and Drug Administration (FDA) as part of combination therapy for treatment of adults with MDR TB (Mahajan, 2013), the drug's potential risks, which include death, have raised concerns, and this has resulted in the drug being mandated for use only when there are no other alternative treatment options available (Mahajan, 2013).

Globally, plants have been reported for traditional use as medicine since antiquity for treatment of various diseases including TB. In South Africa, several ethnobotanical surveys 
documenting the traditional use of plants against TB have been conducted. These include surveys done in Limpopo, Free State, and Eastern Cape (Semenya and Maroyi, 2013; Phungula et al., 2014; Famewo et al., 2017, Madikizela et al., 2017). Worldwide, there are many reports of primary screenings of crude plant extracts by researchers with the intention of identifying new anti-TB compounds (Cantrell et al., 1998; Molina-Salinas et al., 2006; Green et al., 2010; Luo et al., 2011, Masoko and Nxumalo, 2013; Nguta et al., 2016). The influence of plant use based traditional medicine on drug discovery has been profound, with several clinically active drugs derived from them. As a result, structurally diverse compounds with anti-TB activity have been isolated from plants showing potential against TB causative bacterial strains, and several of them have shown significant antimycobacterial activities (Ramos et al., 2008, Fyhrquist et al., 2014). However, more plants still need to be investigated for their efficacy. In 2008 a review on the antimycobacterial potential of South African medicinal plants highlighted that close to 180 plants are used in local traditional medicine but only about $30 \%$ have been tested for antimycobacterial activity, largely only against non-pathogenic mycobacteria (McGaw et al., 2008a).

Further recent work has identified more plant species used to treat TB in southern Africa. In our previous research, plants used in the eastern region of OR Tambo district, Eastern Cape province, South Africa, for traditionally treating TB were documented (Madikizela et al., 2017). In the present study ten plants from that list were selected for biological analysis. The selection of the plants used in this study followed scrutiny of available literature for reported antimycobacterial studies and discovering that such information was lacking. Therefore, the aim of this study was to determine the antimycobacterial effect of ten selected plants used in the eastern region of OR Tambo district in traditional anti-TB therapy. Since most in vitro antimycobacterial studies have been conducted against non-pathogenic, saprophytic Mycobacterium species and studies reporting correlations between activity of such species and pathogenic species are sparse and contradictory, it is useful to compare activities of the extracts against different Mycobacterium species to determine which non-pathogenic Mycobacterium species correlates best to the pathogenic $M$. tuberculosis in terms of susceptibility to plant extracts. More information is required to support the use of preliminary antimycobacterial screening methods using fast-growing saprophytic mycobacteria, or slower-growing species with lower safety concerns such as M. bovis BCG (McGaw et al., 2008b). 
The World Health Organisation (WHO) continues to encourage the use of medicinal plants to supplement their health care program, provided that they are proven to be safe (Hong and Lyu, 2011). Worldwide, the potential toxicity of some of the more popularly used herbal remedies is a cause for concern, thus, it is necessary to assess their toxicity to ensure their relative safety as it would be dangerous to assume that all plant extracts are safe to use. Therefore, this study further aimed to determine in vitro if extracts from selected medicinal plants were cytotoxic or genotoxic.

\section{Materials and methods}

\subsection{Plant collection and extraction}

Specimens of ten selected plants; Gerrardina foliosa Oliv., Haemanthus albiflos Jacq, Heteromorpha trifoliata (H.L. Wendl.) Eckl. \& Zeyh., Hypoxis colchicifolia Baker, Pachycarpus concolor E. Mey., Phymaspermum acerosum (DC.) Källersjö, Pittosporum viridiflorum Sims, Protorhus longifolia (Bernh.) Engl, Pterocelastrus echinatus N.E. Br., and Talinum caffrum (Thunb.) Eckl. \& Zeyh. were collected from different provinces in South Africa (Gauteng, Mpumalanga, KwaZulu-Natal and Eastern Cape), and identified at the HGWJ Schweickerdt Herbarium, University of Pretoria, South Africa. Dried, ground plant material (2 g) was extracted non-sequentially with $20 \mathrm{ml}$ of $100 \%$ acetone, $70 \%$ ethanol, and cold water through sonication for $1 \mathrm{hr}$. The decoction (referred to as the hot water extract) was prepared by extracting $2 \mathrm{~g}$ of dried material in $30 \mathrm{ml}$ of distilled water and boiling for 5 minutes, cooled for $1 \mathrm{~h}$ at room temperature, and then filtered. All the extracts were filtered through Whatman No 1. filter paper, and the filtrates were concentrated using a rotary evaporator and stored at $8^{\circ} \mathrm{C}$ until use.

\subsection{Antimycobacterial assay}

The Department of Agriculture, Forestry and Fisheries of South Africa granted approval under Section 20 of the Animal Diseases Act to conduct this research. The WHO (2012) biosafety standards for handling of pathogenic Mycobacterium strains were followed, and they included working in a Biosafety Level 2 Laboratory, wearing a protective gear, following the required procedure for decontamination and disposal of waste. All the experiments were performed in the laboratory approved by the Institutional Biosafety 
Committee for Mycobacterial Cultures by University of Pretoria, in the Department of Veterinary Tropical Diseases.

Five non-pathogenic Mycobacterium strains, three from the American Type Culture Collection (ATCC), one from the National Collection of Type Cultures (NCTC), and one Pasteur strain; fast growing $\{M$. fortuitum (ATCC 6841), and $M$. smegmatis (ATCC 1441)\}, and slow growing $\{M$. bovis BCG P1172, M. gordonae (ATCC 14470), and M. aurum (NCTC 10437) \} were used for the antimycobacterial assay against all extracts prepared in this study. The Mycobacterium cultures were maintained on Middlebrook agar supplemented with 10\% (v/v) oleic acid, albumin, dextrose and catalase (OADC) and glycerol, and were cultured on glycerol and OADC-supplemented Middlebrook broth. The cultures were incubated at $37^{\circ} \mathrm{C}$ for $24-48 \mathrm{~h}$ for M. fortuitum and M. smegmatis, 3-4 days for M. aurum, and 14-21 days for M. bovis BCG and M. gordonae. Three pathogenic Mycobacterium strains were used to screen the antimycobacterial activity of extracts that showed MIC values less than $1 \mathrm{mg} / \mathrm{ml}$ against at least 3 non-pathogenic Mycobacterium strains. The pathogenic $M$. tuberculosis H37RV ATCC 27294 and M. tuberculosis ATCC 25177 were maintained on Lowenstein-Jensen (LJ) slants supplemented with glycerol, or pyruvate in the case of $M$. bovis ATCC 27290, for a month, and colonies were transferred into $3 \mathrm{ml}$ of supplemented Middlebrook broth, homogenized by vortexing, then the larger particles were allowed to settle. All the test inoculum were prepared in supplemented Middlebrook broth, and adjusted to McFarland standard 1 equivalent to $3.0 \times 10^{8}$ diluted to a final density of $5 \times 10^{5} \mathrm{CFU} / \mathrm{ml}$ in the medium.

A microdilution assay according to Eloff (1998) and Jadaun et al. (2007) in a 96 well microtitre plate was used to determine the MIC values of fifty-eight extracts from the ten plants. Extracts $(10 \mathrm{mg} / \mathrm{ml})$ prepared in $10 \%$ dimethylsulfoxide (DMSO) and water (for water extracts) were serially diluted twofold $(100 \mu \mathrm{l})$ with OADC-supplemented Middlebrook 7H9 broth down the wells of a 96 well microtitre plate. Isoniazid, streptomycin and rifampicin were used as positive controls, whereas 10\% DMSO, water, inoculum and OADCsupplemented Middlebrook 7H9 broth were negative controls. Then, $100 \mu \mathrm{l}$ of mycobacterial cultures were added in all the wells. The plates were sealed with parafilm and incubated for 24-48 h (M. smegmatis and M. fortuitum), 3-4 days (M. aurum) 7-10 days (M. gordonae and M. bovis, M. bovis BCG, M. tuberculosis H37RV and M. tuberculosis) at $37^{\circ} \mathrm{C}$. After the incubation period, MIC values were determined by adding $40 \mu 1$ of $0.2 \mathrm{mg} / \mathrm{ml}$ of freshly prepared $p$-iodonitro-tetrazolium chloride (INT) solution. Colour detection after the addition 
of INT was read as soon as colour became visible in the untreated control wells. MIC values were read as the concentrations where a marked reduction in colour formation corresponding to inhibition of mycobacterial growth was noted. Concentrations were tested in triplicate and the experiments were repeated twice. Correlations between the MIC values of the various Mycobacterium strains used and the pathogenic ATCC strain of M. tuberculosis were calculated using Microsoft Excel 2010 software (Kabongo-Kayoka et al., 2016).

\subsection{Cytotoxicity assay}

The cytotoxicity of plant extracts was determined using the [3-(4,5-dimethylthiazol-2-yl)-2,5diphenyltetrazolium bromide] (MTT) assay according to Mosmann (1983). Extracts with antimycobacterial activity against at least three Mycobacterium strains were evaluated for cytotoxicity against the African green monkey kidney (Vero) and bovine dermis cells obtained from the Department of Veterinary Tropical Diseases (University of Pretoria), South Africa. The cells were cultured in sterile minimal essential medium (MEM) supplemented with $0.1 \%$ gentamicin and $5 \%$ foetal calf serum (FCS) in a $75 \mathrm{~cm}^{2}$ flask, and incubated at $37^{\circ} \mathrm{C}$ in $5 \% \mathrm{CO}_{2}$. After a week of incubation, the cells were harvested using $3 \mathrm{ml}$ of trypsinEDTA, centrifuged for $5 \mathrm{~min}$ at $200 \mathrm{x} \mathrm{g}$, counted using a Neubauer haemocytometer, and resuspended in MEM to a concentration of 1 x $10^{5}$ cells per well. The cells $(100 \mu \mathrm{l})$ were added to all the wells of columns 2-11 of sterile flat bottomed 96 well microtitre plates at a final concentration of 10000 cells per well, and $200 \mu$ of MEM was added to all the wells of columns 1 and 12. The microtitre plates were incubated at $37^{\circ} \mathrm{C}$ in $5 \% \mathrm{CO}_{2}$ overnight. The extracts dissolved in $100 \%$ DMSO to a concentration of $100 \mathrm{mg} / \mathrm{ml}$ were diluted to a concentration ranging from 0.0075 to $1 \mathrm{mg} / \mathrm{ml}$ in MEM and added to wells $(100 \mu \mathrm{l})$ in quadruplicate. Doxorubicin hydrochloride (Pfizer) was used as a positive control, and negative controls (untreated cells, MEM, and DMSO) were also included. The microtitre plates were incubated at $37^{\circ} \mathrm{C}$ in $5 \% \mathrm{CO}_{2}$ for $48 \mathrm{~h}$. After the $48 \mathrm{~h}$ incubation period, the test samples containing MEM were aspirated from the wells, and the cells were washed with 200 $\mu \mathrm{l}$ of phosphate buffered saline (PBS). Fresh MEM $(200 \mu \mathrm{l})$ and $30 \mu \mathrm{l}$ of MTT $(5 \mathrm{mg} / \mathrm{ml}$ stock solution dissolved in PBS) was added to all the wells and the microtitre plates were incubated at $37^{\circ} \mathrm{C}$ in $5 \% \mathrm{CO}_{2}$ for $4 \mathrm{~h}$. Following $4 \mathrm{~h}$ of incubation, $50 \mu \mathrm{l}$ of DMSO were added to each well, and the plates were shaken gently until the crystals were dissolved. A microplate reader at a wavelength of $570 \mathrm{~nm}$ (reference wavelength of $630 \mathrm{~nm}$ ) was used to measure the amount of MTT reduction. MEM containing wells in columns 1 and 12 were used as blanks. The results were interpreted as percentage of the control wells and $\mathrm{LC}_{50}$ 
values were noted as the lethal concentration at which $50 \%$ of the cells were killed). The following formula was used to calculate percentage cell viability:

\section{Percentage cell viability $=\left\{\frac{\text { Mean absorbance of sample }}{\text { Mean absorbance of control }}\right\} \times 100$}

The $\mathrm{LC}_{50}$ values were calculated as the concentration of the test sample that resulted in $50 \%$ reduction of absorbance compared to untreated cells. From the MIC of the extracts against tested Mycobacterium strains and $\mathrm{LC}_{50}$ values, the selectivity index values for each extract were calculated using the following formula:

$S I=\frac{L C 50}{M I C}$

\subsection{Genotoxicity}

In this study, extracts that showed MIC values less than $1 \mathrm{mg} / \mathrm{ml}$ against at least 3 Mycobacterium strains were tested for genotoxicity. The Salmonella microsome assay according to Maron and Ames (1983) modified by Mortelmans and Zeiger (2000) was used to determine the genotoxicity of selected extracts. Two Salmonella typhimurium tester strains, TA98 and TA100, were used for the assay, which was done without metabolic activation. Briefly, stock bacterial cultures $(100 \mu \mathrm{l})$ incubated in nutrient broth No.2 at $37^{\circ} \mathrm{C}$ for $16 \mathrm{~h}$ were added $(100 \mu \mathrm{l})$ to test samples $(100 \mu \mathrm{l})$ followed by $500 \mu \mathrm{l}$ of phosphate buffer saline and $2 \mathrm{ml}$ of top agar $(2 \mathrm{ml})$ containing biotin/histidine $(0.5 \mathrm{mM})$. A positive control, 4nitroquinoline-1-oxide (4-NQO) at a concentration of $2 \mu \mathrm{g} / \mathrm{ml}$ was used, and two negative controls, sterile distilled water and 10\% DMSO, were also used. The mixture was vortexed, and poured on minimal agar plates and incubated for $48 \mathrm{~h}$ at $37^{\circ} \mathrm{C}$. All samples were tested in triplicate. The absence or presence of toxicity was examined by observing the background bacterial growth.

\subsection{Phytochemical analysis of selected plant extracts}

The phytochemical investigation of selected extracts was done to obtain an overall picture of the number of compounds present in plant extracts by performing thin layer chromatography (TLC) analysis. The extracts were dissolved in their respective solvents of extraction such as acetone, ethanol and water. They were then spotted at the bottom of an aluminium TLC plate coated with silica gel. The TLC plates were developed in eluents made up of hexane:ethyl acetate (8:2 and 7:3), methanol:water (9:1), ethyl acetate: methanol: formic acid (8:2:1) and ethyl acetate: water $(10 \mathrm{ml}: 10 \mu \mathrm{l})$. At the end of each run, the chromatograms were sprayed 
with vanillin:sulphuric acid in methanol and dried using a heat gun to visualise the bands. The retention factor (Rf), defined as the distance travelled by the compound divided by the distance travelled by the solvent was determined.

\section{Results and Discussion}

\subsection{Antimycobacterial activity}

In vitro antimycobacterial activity of fifty-eight extracts from ten plants; $G$. foliosa (bark), $H$. albiflos (leaves and bulb), H. trifoliata (leaves), H. colchicifolia (bulb), P. concolor (root), P. acerosum (leaves and roots), P. viridiflorum (bark and leaves), P. longifolia (bark and leaves), P. echinatus (bark and leaves), and T. caffrum (rhizome) against non-pathogenic Mycobacterium strains and selected extracts (twenty-nine) against pathogenic strains was determined. The results of the MIC values are presented in Table 2. Although, there are several techniques that are used to determine antimycobacterial activity, an exact cut off value for activity of plant crude extracts has not yet been established. However in previously reported antimycobacterial studies, extracts with MIC values $\leq 0.1 \mathrm{mg} / \mathrm{ml}$ were considered to have significant activity; moderate activity was between 0.1 and $0.63 \mathrm{mg} / \mathrm{ml}$ and weak or poor activity with MICs $>0.63 \mathrm{mg} / \mathrm{ml}$ (Kuete and Efferth, 2010). According to the literature (MolinaSalinas et al., 2006), those extracts with MIC of $125 \mu \mathrm{g} / \mathrm{ml}$ or below are considered active against Mycobacterium species. Therefore, analysis of the antimycobacterial activity of crude extracts in the current study was based on the procedures mentioned above. The tested extracts (58) showed a wide range of antimycobacterial activity from significant (eight) to moderate (43) and poor (13) with MIC values ranging from 0.02-2.50 mg/ml against nonpathogenic strains, and the MIC values of twenty-nine extracts tested against pathogenic $M y$ cobacterium strains also ranged from $0.02-2.50 \mathrm{mg} / \mathrm{ml}$. The best MIC value $=0.02 \mathrm{mg} / \mathrm{ml}$ was observed with $P$. acerosum leaves (ethanol; against $M$. smegmatis and $M$. bovis BCG, and water; against $M$. bovis BCG) and roots (ethanol; against $M$. smegmatis and M. bovis, and water; against $M$. fortuitum and $M$. bovis BCG) extracts. The extracts of $P$. acerosum roots and leaves showed noteworthy to moderate antimycobacterial activity against all tested $M y$ cobacterium strains with MIC values ranging from 0.02 to $0.63 \mathrm{mg} / \mathrm{ml}$. Interesting antimycobacterial activity was observed with the leaf extracts of $H$. trifoliata against $M$. bovis BCG, M. tuberculosis H37RV, M. tuberculosis (ethanol) and M. fortuitum (hot water) at MIC values $=0.08 \mathrm{mg} / \mathrm{ml}$. The rest of the extracts of $H$. trifoliata leaves, with the exception of acetone extract, showed moderate antimycobacterial activity against at least 4 non-pathogenic $\mathrm{Myco-}$ bacterium strains, and all the pathogenic strains. Several compounds, namely sarisan, ger 
Table 1: Pharmacological studies previously done on the selected traditionally used anti-tuberculosis plant species

\begin{tabular}{|c|c|c|c|}
\hline $\begin{array}{l}\text { Family and botanical } \\
\text { name }\end{array}$ & $\begin{array}{l}\text { Voucher specimen } \\
\text { number }\end{array}$ & Pharmacological research done & References \\
\hline $\begin{array}{l}\text { Amaryllidaceae } \\
\text { Haemanthus albiflos Jacq }\end{array}$ & PRU122514 & $\begin{array}{l}\text { Antiviral against Moloney murine } \\
\text { leukemia and HIV. Cytotoxicity, phy- } \\
\text { tochemically investigated and yielded } \\
\text { homolycorine, albomaculine and O- } \\
\text { methyl-lycorenium salt. }\end{array}$ & $\begin{array}{l}\text { Husson et al., 1994, } 1995 \\
\text { and } 1997, \text { Crouch et al., } \\
2005\end{array}$ \\
\hline $\begin{array}{l}\text { Anacardiaceae } \\
\text { Protorhus longifolia } \\
\text { (Bernh.) Engl }\end{array}$ & PRU122537 & $\begin{array}{l}\text { Antibacterial, antimycobacterial an- } \\
\text { tiplatelet aggregation, and cytotoxicity } \\
\text { activity. Two lanostane triterpenes } \\
\text { isolated, tested for antibacterial, anti- } \\
\text { fungal, antiplasmodial, antiplatelet, } \\
\text { cytotoxicity, antiinflammatory and } \\
\text { antihyperlipidemic properties. }\end{array}$ & $\begin{array}{l}\text { Suleiman et al., 2010; Mosa } \\
\text { et al., 2011; Machaba et al., } \\
\text { 2014; Kabongo-Kayoka et } \\
\text { al., } 2016\end{array}$ \\
\hline $\begin{array}{l}\text { Apiaceae } \\
\text { Heteromorpha trifoliata } \\
\text { (H.L. Wendl.) Eckl. \& } \\
\text { Zeyh. }\end{array}$ & PRU122545 & $\begin{array}{l}\text { Antibacterial, anthelmintic, antiamoe- } \\
\text { bic, antifungal, genotoxicity activity, } \\
\text { and pharmacological effect on smooth } \\
\text { muscle evaluated. Antifungal com- } \\
\text { pounds: germacrene-D, sabinene, al- } \\
\text { lylbenzene sarisan and falcarindiol } \\
\text { isolated. }\end{array}$ & $\begin{array}{l}\text { Villegas et al., 1988; } \\
\text { Mwangi et al., 1994; Ka- } \\
\text { terere and Perry, 2000; } \\
\text { McGaw et al., 2000; Adamu } \\
\text { et al., } 2013\end{array}$ \\
\hline $\begin{array}{l}\text { Apocynaceae } \\
\text { Pachycarpus concolor E. } \\
\text { Mey. }\end{array}$ & B. Madikizela 14 & - & \\
\hline $\begin{array}{l}\text { Compositae } \\
\text { Phymaspermum acerosum } \\
\text { (DC.) Källersjö }\end{array}$ & PRU124356 & - & \\
\hline $\begin{array}{l}\text { Celastraceae } \\
\text { Pterocelastrus echinatus } \\
\text { N.E.Br. }\end{array}$ & PRU122556 & - & \\
\hline $\begin{array}{l}\text { Gerrardinaceae } \\
\text { Gerrardina foliosa Oliv. }\end{array}$ & B. Madikizela 8 & - & \\
\hline $\begin{array}{l}\text { Hypoxidaceae } \\
\text { Hypoxis colchicifolia } \\
\text { Baker }\end{array}$ & PRU 124355 & $\begin{array}{l}\text { Anti-inflammatory, antimalarial, an- } \\
\text { thelmintic, antipyretic, and } \mathrm{GABA}_{\mathrm{A}^{-}} \\
\text {benzodia zepine receptor activity. } \\
\text { Norlignan glycosides, geraniol glyco- } \\
\text { side and } \beta \text {-sitosterol isolated. }\end{array}$ & $\begin{array}{l}\text { Risa et al., 2004; Aremu et } \\
\text { al., 2010; Bassey et al., } 2014\end{array}$ \\
\hline $\begin{array}{l}\text { Pittosporaceae } \\
\text { Pittosporum viridiflorum } \\
\text { Sims }\end{array}$ & PRU 120025 & $\begin{array}{l}\text { Antimicrobial, antifungal, anthelmin- } \\
\text { tic, antiamoebic, in vitro and in vivo } \\
\text { (antimalarial and toxicity), antiplas- } \\
\text { modial, insecticidal and antiproteus } \\
\text { effects. Analysis of phytochemical and } \\
\text { antioxidant potential. } \delta \text { - cadinene, } \\
\text { alpha-cadinol, decanal, sabinene, } \beta \text { - } \\
\text { elemene and pittoviridoside isolated } \\
\text { and tested for antimicrobial activity. } \\
\text { Pittoviridoside tested for cytotoxicity. }\end{array}$ & $\begin{array}{l}\text { Ramanandraibe et al., 2001; } \\
\text { McGaw et al., 2000; Seo et } \\
\text { al., 2002; Clarkson et al., } \\
\text { 2004; van Vuuren and } \\
\text { Viljoen, 2006; John et al., } \\
\text { 2007; Muthaura et al., 2007; } \\
\text { Maharaj et al., 2011; Otang } \\
\text { et al., 2012; Cock and van } \\
\text { Vuuren, 2014 }\end{array}$ \\
\hline $\begin{array}{l}\text { Talinaceae } \\
\text { Talinum caffrum (Thunb.) } \\
\text { Eckl. \& Zeyh. }\end{array}$ & B. Madikizela 1 & - & \\
\hline
\end{tabular}

- =No reported pharmacological studies 
Table 2: Antimycobacterial activity of extracts from traditionally used anti-tuberculosis plants in the eastern region of OR Tambo district

\begin{tabular}{|c|c|c|c|c|c|c|c|c|c|}
\hline \multirow{3}{*}{ Plant species and part used } & \multirow{3}{*}{ Extracts } & \multicolumn{8}{|c|}{ Minimum inhibitory concentration values $(\mathrm{mg} / \mathrm{ml})$} \\
\hline & & \multicolumn{5}{|c|}{ Non-pathogenic Mycobacterium strains } & \multicolumn{3}{|c|}{ Pathogenic Mycobacterium strains } \\
\hline & & M. sm & M.fo & M. au & M. bo BCG & M. go & M. bo & M.tb Rv & M. $t b$ \\
\hline \multirow[t]{4}{*}{ Gerrardina foliosa (bark) } & Acetone & 0.63 & 0.63 & 1.25 & 2.50 & 1.25 & - & - & - \\
\hline & Ethanol & 1.25 & 2.50 & 0.63 & 2.50 & 1.25 & - & - & - \\
\hline & Water & 1.25 & 2.50 & 0.63 & 1.25 & 2.50 & - & - & - \\
\hline & Hot water & 1.25 & 0.31 & 0.63 & 0.63 & 2.50 & 0.63 & 0.31 & 0.31 \\
\hline \multirow[t]{3}{*}{ Haemanthus albiflos (leaf) } & Acetone & 0.63 & 0.63 & 2.50 & 2.50 & 2.50 & - & - & - \\
\hline & Ethanol & 2.50 & 2.50 & 2.50 & 2.50 & 2.50 & - & - & - \\
\hline & Water & 2.50 & 2.50 & 2.50 & 2.50 & 2.50 & - & - & - \\
\hline \multirow[t]{3}{*}{ Haemanthus albiflos (bulb) } & Acetone & 1.25 & 2.50 & 2.50 & 0.63 & 0.63 & - & - & - \\
\hline & Ethanol & 2.50 & 1.25 & 2.50 & 2.50 & 2.50 & - & - & - \\
\hline & Water & 1.25 & 1.25 & 2.50 & 2.50 & 2.50 & - & - & - \\
\hline \multirow[t]{4}{*}{ Heteromorpha trifoliata (leaf) } & Acetone & 1.25 & 1.25 & 1.25 & 0.31 & 1.25 & 2.50 & 1.25 & 5.00 \\
\hline & Ethanol & 0.63 & 0.31 & 0.63 & 0.08 & 0.08 & 0.16 & 0.08 & 0.08 \\
\hline & Water & 0.63 & 0.63 & 0.63 & 0.63 & 0.63 & 0.31 & 0.16 & 0.16 \\
\hline & Hot water & 0.63 & 0.08 & 0.63 & 2.50 & 0.63 & 0.63 & 0.16 & 0.31 \\
\hline \multirow[t]{4}{*}{ Hypoxis colchicifolia (bulb) } & Acetone & 0.63 & 0.63 & 0.63 & 0.63 & 0.63 & 0.31 & 0.31 & 0.63 \\
\hline & Ethanol & 1.25 & 2.50 & 0.63 & 0.63 & 0.63 & 0.63 & 0.31 & 0.31 \\
\hline & Water & 0.63 & 0.63 & 0.63 & 0.31 & 0.31 & 0.63 & 0.31 & 0.16 \\
\hline & Hot water & 0.31 & 0.08 & 0.63 & 0.31 & 0.31 & 0.16 & 0.31 & 0.31 \\
\hline \multirow[t]{4}{*}{ Pachycarpus concolor (root) } & Acetone & 1.25 & 1.25 & 2.50 & 0.31 & 1.25 & - & - & - \\
\hline & Ethanol & 1.25 & 2.50 & 2.50 & 2.50 & 2.50 & - & - & - \\
\hline & Water & 1.25 & 2.50 & 1.25 & 2.50 & 2.50 & - & - & - \\
\hline & Hot water & 2.50 & 2.50 & 1.25 & 0.31 & 1.25 & - & - & - \\
\hline \multirow[t]{3}{*}{ Phymaspermum acerosum (leaf) } & Acetone & 0.31 & 0.31 & 0.31 & 0.31 & 0.16 & 0.63 & 0.31 & 0.63 \\
\hline & Ethanol & 0.02 & 0.16 & 0.16 & 0.02 & 0.16 & 0.02 & 0.16 & 0.16 \\
\hline & Water & 0.16 & $\mathbf{0 . 0 8}$ & $\mathbf{0 . 0 8}$ & 0.02 & 0.16 & 0.04 & 0.08 & $\mathbf{0 . 0 8}$ \\
\hline \multirow[t]{3}{*}{ Phymaspermum acerosum (root) } & Acetone & 0.16 & 0.16 & 0.08 & 0.16 & 0.31 & 0.31 & 0.31 & 0.16 \\
\hline & Ethanol & 0.02 & 0.31 & 0.08 & 0.02 & 0.63 & 0.16 & 0.31 & 0.31 \\
\hline & Water & 0.08 & 0.02 & 0.08 & 0.02 & 0.63 & 0.04 & 0.04 & 0.04 \\
\hline
\end{tabular}




\begin{tabular}{|c|c|c|c|c|c|c|c|c|c|}
\hline \multirow[t]{4}{*}{ Pittosporum viridiflorum (leaf) } & Acetone & 0.63 & 2.50 & 1.25 & 0.31 & 0.31 & 0.16 & 0.31 & 0.31 \\
\hline & Ethanol & 2.50 & 0.63 & 1.25 & 0.31 & 0.31 & 0.63 & 1.25 & 2.50 \\
\hline & Water & 1.25 & 0.63 & 2.50 & 0.31 & 2.5 & - & - & - \\
\hline & Hot water & 2.50 & 2.50 & 2.50 & 0.31 & 2.5 & - & - & - \\
\hline \multirow[t]{4}{*}{ Pittosporum viridiflorum (bark) } & Acetone & 0.63 & 0.63 & 2.50 & 0.63 & 1.25 & 0.63 & 2.50 & 2.50 \\
\hline & Ethanol & 0.63 & 0.31 & 2.50 & 0.63 & 1.25 & 0.63 & 1.25 & 1.25 \\
\hline & Water & 0.63 & 0.63 & 0.63 & 0.63 & 1.25 & 0.63 & 1.25 & 1.25 \\
\hline & Hot water & 2.50 & 2.50 & 2.50 & 0.63 & 1.25 & - & - & - \\
\hline \multirow[t]{4}{*}{ Protorhus longifolia (bark) } & Acetone & 2.50 & 2.50 & 2.50 & 1.25 & 1.25 & - & - & - \\
\hline & Ethanol & 2.50 & 2.50 & 2.50 & 1.25 & 2.50 & - & - & - \\
\hline & Water & 2.50 & 2.50 & 2.50 & 0.31 & 2.50 & - & - & - \\
\hline & Hot water & 2.50 & 0.16 & 0.63 & 0.63 & 1.25 & - & - & - \\
\hline \multirow[t]{4}{*}{ Protorhus longifolia (leaf) } & Acetone & 0.08 & 0.16 & 0.16 & 0.08 & 0.16 & 0.16 & 0.31 & 0.16 \\
\hline & Ethanol & 0.31 & 0.31 & 0.31 & 0.16 & 1.25 & 0.63 & 1.25 & 1.25 \\
\hline & Water & 0.63 & 0.63 & 1.25 & 2.50 & 1.25 & - & - & - \\
\hline & Hot water & 0.63 & 0.63 & 0.31 & 2.50 & 1.25 & 0.31 & 0.16 & 0.31 \\
\hline \multirow[t]{4}{*}{ Pterocelastrus echinatus (bark) } & Acetone & 0.31 & 0.31 & 0.63 & 0.31 & 0.63 & 0.16 & 0.16 & 0.31 \\
\hline & Ethanol & 0.31 & 0.31 & 0.63 & 0.63 & 0.63 & 0.31 & 0.31 & 0.63 \\
\hline & Water & 1.25 & 2.50 & 1.25 & 0.63 & 1.25 & - & - & - \\
\hline & Hot water & 0.63 & 0.63 & 0.31 & 0.31 & 0.63 & 0.31 & 0.16 & 0.16 \\
\hline \multirow[t]{4}{*}{ Pterocelastrus echinatus (leaf) } & Acetone & 0.63 & 0.63 & 1.25 & 0.63 & 0.63 & 0.63 & 0.31 & 0.31 \\
\hline & Ethanol & 0.31 & 0.31 & 0.63 & 0.63 & 0.63 & 0.63 & 0.16 & 0.16 \\
\hline & Water & 0.63 & 1.25 & 1.25 & 0.63 & 0.63 & 0.31 & 1.25 & 0.63 \\
\hline & Hot water & 1.25 & 2.50 & 2.50 & 1.25 & 1.25 & 0.63 & 1.25 & 0.31 \\
\hline \multirow[t]{4}{*}{ Talinum caffrum (rhizome) } & Acetone & 1.25 & 1.25 & 2.50 & 2.50 & 2.50 & - & - & - \\
\hline & Ethanol & 2.50 & 2.50 & 1.25 & 2.50 & 2.50 & - & - & - \\
\hline & Water & 1.25 & 1.25 & 2.50 & 2.50 & 2.50 & - & - & - \\
\hline & Hot water & 2.50 & 1.25 & 2.50 & 2.50 & 2.50 & - & - & - \\
\hline Isoniazid & & $>0.1$ & $>0.1$ & $>0.1$ & $>0.1$ & $>0.1$ & & 0.03 & \\
\hline Rifampicin & & 0.03 & 0.03 & 0.01 & 0.03 & 0.01 & & 0.08 & \\
\hline Streptomycin & & $>0.1$ & $>0.1$ & $>0.1$ & $>0.1$ & $>0.1$ & & & \\
\hline
\end{tabular}


macrene-D, sabinene, allylbenzene and falcarindiol have reportedly been isolated from $H$. trifoliata leaves and they could be responsible for the observed antimycobacterial activity (Villegas et al., 1988; Recio et al., 1995). Falcarindiol previously isolated from the whole herb of Anethum graveolens showed noteworthy antimycobacterial activity against $M$. fortuitum, M. aurum, M. smegmatis, M. abscessus and M. phlei with MIC values ranging from 2-4 $\mu \mathrm{g} / \mathrm{ml}$, thus making the compound a potential target for the development of anti-TB drugs (Stavri and Gibbons, 2005). H. colchicifolia (bulb) hot water extract showed noteworthy antimycobacterial activity against $M$. fortuitum with MIC value $=0.08 \mathrm{mg} / \mathrm{ml}$, and all the extracts showed moderate activity towards at least 6 Mycobacterium strains. A phenolic glycoside (3hydroxy-4-O- $\beta$-D-glucopyranosylbenzaldehyde), geraniol glycoside and $\beta$-sitosterol were reported to have been isolated from the bulbs of $H$. colchicifolia and they could be responsible for the antimycobacterial activity observed from this plant, but confirmation of that is still pending (Bassey et al., 2014). For P. longifolia, the acetone leaf extracts showed interesting activity against $M$. smegmatis and $M$. bovis $\mathrm{BCG}$ with $\mathrm{MIC}=0.08 \mathrm{mg} / \mathrm{ml}$, and moderate antimycobacterial activity was observed with the ethanol, and hot water extracts of the same plant against at least 4 Mycobacterium strains. Just like in this study, the leaf acetone extract of $P$. longifolia showed significant antimycobacterial activity against $M$. smegmatis in previous work (Kabongo-Kayoka et al., 2016). The bark is the reported plant part of P. longifolia for traditional use against TB. Although, most extracts from this plant were inactive, it was interesting to observe antimycobacterial activity of the hot water extract against at least 6 strains, although moderate ranging from $0.16-0.63 \mathrm{mg} / \mathrm{ml}$.

Both the bark (acetone, ethanol and hot water) and leaf (acetone, ethanol and water) extracts of $P$. echinatus showed moderate antimycobacterial activity against at least five Mycobacterium strains. Homolycorine, albomaculine, albimanthine, and O-methyl-lycorenium salt reportedly isolated from H. albiflos (Baudoin et al., 1994; Crouch et al., 2005) could be responsible for moderate antimycobacterial activity shown by the leaf acetone extracts of this plant (against M. smegmatis and M. fortuitum) and bulbs (against M. bovis BCG and M. gordonae). The bark and leaf extracts of $P$. viridiflorum demonstrated moderate activity towards at least one strain of Mycobacterium. Pittoviridoside (Seo et al., 2002), sesquiterpene glycoside and its derivatives (Ramandraibe et al., 2001), pentacyclic triterpenoids (Nyabayo et al., 2015), and pentacyclic triterterpenoiol estersaponin (Nyongbela et al., 2013) reportedly isolated from the leaves of this plant could be responsible for the observed activity. For P. concolor, only the acetone extract showed moderate antimycobacterial activity towards at least one 
strain (M. bovis $\mathrm{BCG}, \mathrm{MIC}=0.31 \mathrm{mg} / \mathrm{ml}$ ), while the rest of the extracts showed poor activity. There are different compounds within an extract that may act in synergy, but once isolated, they might demonstrate more activity than the crude extract, therefore, moderate antimycobacterial activity of crude extracts is worthy of further investigation.

Interesting antimycobacterial activity observed with ethanol and water extracts of $P$. $a c$ erosum, $H$. trifoliata and $H$. colchicifolia was encouraging as these are the solvents used for extraction in African traditional medicine, providing some credence for the traditional use of these plants against TB. In spite of the report of T. caffrum for traditional anti-TB use, all the extracts from this plant showed poor antimycobacterial activity, and this could be that antiTB effects of this plant are mediated through immunomodulation or immunostimulation rather than direct mycobacterial inhibition, or that the potentially active constituents from this plant are $\mathrm{pH}$-dependent or need direct in vivo specific enzymes activation (Ríos and Recio, 2005). Therefore, the observed poor antimycobacterial activity of T. caffrum in this study could not preclude its potential anti-TB effect. The pharmacological activities of the plants tested for antimycobacterial potential in this study are displayed in Table 1, and to the best of our knowledge, this is the first report of the antimycobacterial activity of almost all the plants tested, with the exception of $P$. longifolia leaf acetone extract. Additionally, no compounds have been isolated from P. acerosum, P. echinatus, G. foliosa, and P. concolor, therefore, investigation of the constituents from these plants that are responsible for their antimycobacterial activity is highlighted as a worthy future endeavour.

Destructive harvesting of underground plant parts, slow-growth of bulbous and tuberous plants, and tree ring-barking are the major problems in traditional medicine, as some of the plants may not be available for use when needed, due to rarity or extinction. One of the possible solutions proposed by plant conservationists to fight plant extinction is alternative plant part use, particularly encouraging traditional healers to use leaves and twigs instead of bark, roots or bulbs. In this study we prepared extracts from alternative plant parts for some of the plants that were tested to determine if the same activity could be observed from a different plant part, particularly the leaf. For P. acerosum, the leaf extracts showed inhibition of Mycobacterium strains against all the strains tested comparable to root which is the plant part reported for traditional anti-TB use, and importantly the activity of leaf water extract should be noted, as it could be an alternative plant part proposed to traditional healers for use against TB. Comparing the leaf and bark extracts for P. viridiflorum, P. longifolia and P. echinatus, 
the leaves demonstrated antimycobacterial activity although the bark was reported for traditional use against TB. For Haemanthus albiflos leaf and bulb extracts, both plant parts showed comparable results in terms of antimycobacterial activity, with the acetone extracts showing MIC values $=0.63 \mathrm{mg} / \mathrm{ml}$ against two Mycobacterium strains although the bulb was reported to be the plant part used in traditional anti-TB therapy in the eastern region of OR Tambo district. Therefore, these results support plant part substitution, and more in depth studies should investigate whether the leaf, as an alternative part from these plants, has the same secondary metabolites as the bark/roots/stem/bulb.

The findings for predictor of activity against pathogenic Mycobacterium strains amongst the non-pathogenic Mycobacterium strains used in this study are presented in Table 3 as correlation coefficient (r) values. Positive correlations were observed between the activity of non-pathogenic and pathogenic Mycobacterium strains with $\mathrm{r}$ values ranging from 0.02-0.73, whereas negative correlation was observed only with M. bovis BCG on M. tuberculosis ( $\mathrm{r}$ value=-0.05). M. gordonae, $M$. aurum, $M$. smegmatis showed good correlation of activity with M. tuberculosis H37Rv, M. tuberculosis and M. bovis, however, the highest correlation value was observed on $M$. aurum (r value=0.73), suggesting that this strain was a better predictor of activity for pathogenic M. tuberculosis H37Rv in this study among the nonpathogenic strains. M. smegmatis was observed to be a better predictor of activity of $M$. bovis and $M$. tuberculosis with $\mathrm{r}$ values $=0.54$ and 0.49 , respectively. However, in contrast to our finding $M$. bovis BCG was reported as a better predictor of activity with $M$. tuberculosis when compared to M. smegmatis (Altaf et al., 2010). In agreement with our study, M. aurum was reported as a better predictor of anti-M. tuberculosis activity by Aro et al. (2015). In this study, the highest $\mathrm{r}$ value $=0.83$ was observed with pathothogenic $M$. bovis and $M$. tuberculosis. More in depth studies determining which one of the non-pathogenic Mycobacterium strains is a best predictor of activity towards pathogenic Mycobacterium strains are requested

\subsection{Thin layer chromatography (TLC) analysis, a quick chemical fingerprinting of the plant extracts}

Twelve crude extracts with noteworthy antimycobacterial activity against pathogenic strains were selected for the study so as to obtain their fingerprints, and the results are presented in Figures 1a-1d. Analysis of P. acerosum leaf and root (acetone and ethanol) extracts in hexane and ethyl acetate $(8: 2)$ showed the presence of at least 3 nonpolar compounds, with two that 
Table 3: Pearson's correlation coefficient (r) between minimum inhibitory concentration values of eight tested Mycobacterium strains

\begin{tabular}{|c|c|c|c|c|c|c|c|c|}
\hline & $M . s$ & M. fo & M. $a u$ & $\begin{array}{l}\text { M.bo } \\
\text { BCG }\end{array}$ & M. go & M. bov & $M . t b \mathrm{RV}$ & M. $t b$ \\
\hline M.s & 1 & & & & & & & \\
\hline M. fo & 0.67 & 1 & & & & & & \\
\hline M. $a u$ & 0.66 & 0.55 & 1 & & & & & \\
\hline M. bo BCG & 0.33 & 0.32 & 0.43 & 1 & & & & \\
\hline M. go & 0.62 & 0.50 & 0.67 & 0.63 & 1 & & & \\
\hline M. bo & 0.54 & 0.25 & 0.35 & 0.12 & 0.41 & 1 & & \\
\hline M. $t b \mathrm{Rv}$ & 0.38 & 0.25 & 0.73 & 0.02 & 0.42 & 0.44 & 1 & \\
\hline M. $t b$ & 0.49 & 0.14 & 0.43 & -0.05 & 0.31 & 0.83 & 0.69 & 1 \\
\hline
\end{tabular}

M. sm= Mycobacterium smegmatis, M. fo= Mycobacterium fortuitum, M. au= Mycobacterium aurum, M. bo BCG= Mycobacterium bovis BCG, M. go= Mycobacterium gordonae, M. tb Rv= Mycobacterium tuberculosis H37RV, M. tb= Mycobacterium tuberculosis, M. bo= Mycobacterium bovis, 
seemed to be similar based on the Rf values observed (Figure 1a). The water extracts of $P$. acerosum (leaf and root) showed 3 highly polar compounds in ethyl acetate and water (10 $\mathrm{ml}: 30 \mu \mathrm{l}$ ) with one common in both samples with the $\mathrm{Rf}$ value $=0.55$ (Figure1d). As seen in figure $1 \mathrm{~b}, P$. longifolia leaf acetone extract showed 5 non-polar compounds, with one major which had an $\mathrm{Rf}$ value $=0.88$, and according to literature, non-polar compounds have been isolated from this plant part (Ntuli, 2005). Four non-polar compounds were observed on $P$. echinatus bark hot water extracts (Figure 1b) and highly polar compounds were observed on the leaf ethanol extracts of the same plant (Figure 1c). Ethanol and water leaf extracts of $H$. trifoliata showed at least 2 polar compounds (Figure 1c), and two polar compounds were reportedly isolated from the leaf methanol extract of the same plant (Recio et al, 1995).
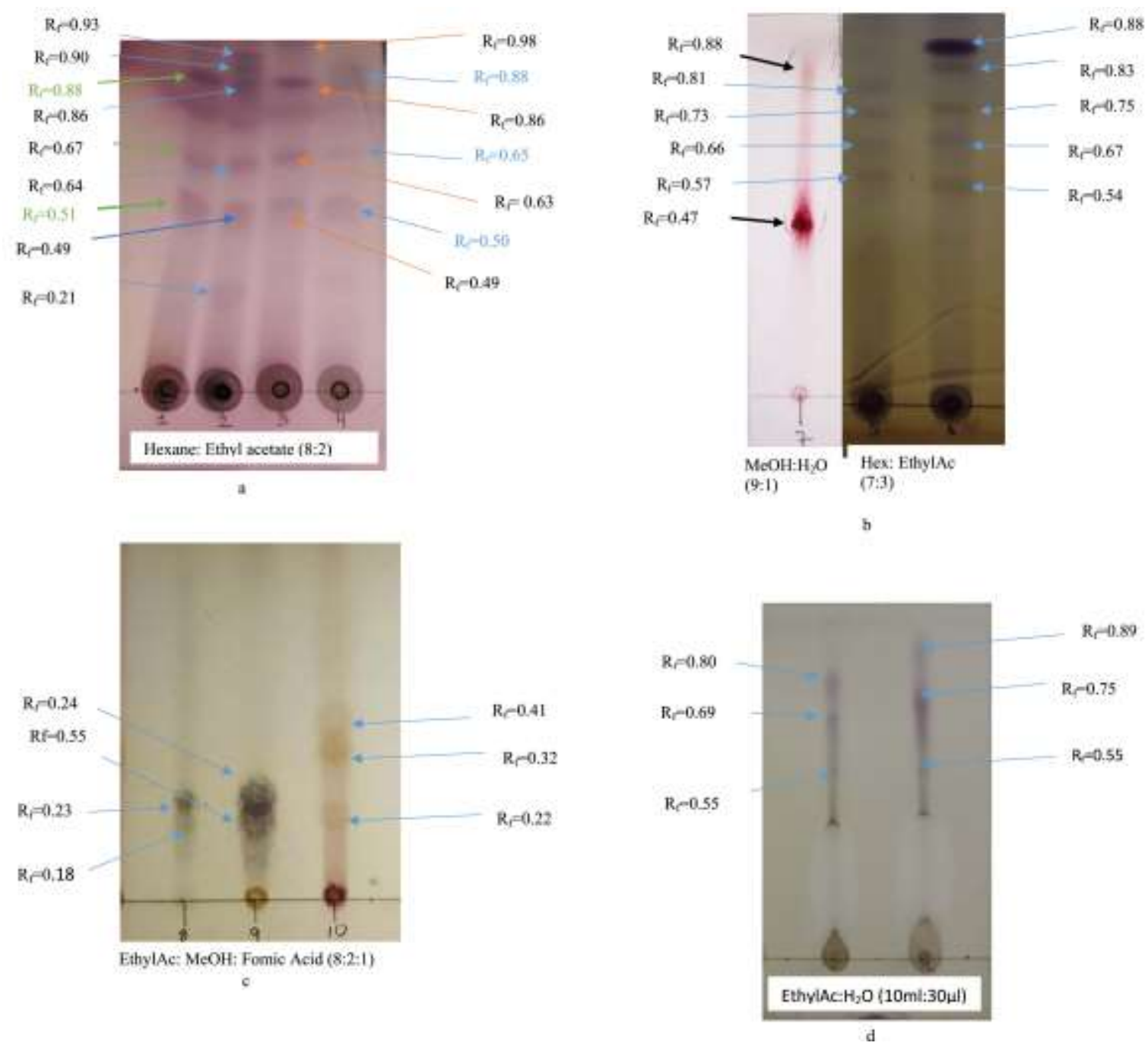

Fig. 1. a: TLC profiling of $P$. acerosum leaf $(1=$ acetone, $3=$ ethanol $)$ and root $(2=$ acetone, $4=$ ethanol $)$ extracts. b: TLC profiling of $P$. echinatus bark $(7=$ hot water $)$ and leaf $(5=$ acetone $)$, as well as $P$. longifolia leaf $(6=$ acetone $)$ extracts. c: TLC profiling of $H$. trifoliata leaf $(8=$ ethanol, $9=$ water $)$ and $P$. echinatus leaf $(10=$ ethanol) extracts. d: TLC profiling of $P$. acerosum leaf $(11=$ water $)$ and root $(12=$ water $)$ extracts. 


\subsection{Cytotoxicity}

Although several studies have led to the validation of some plant derived traditional remedies, research has demonstrated that medicinal plants are potentially toxic in both in vitro and in vivo assays, thus they should be used cautiously (Santin et al., 2011). In vitro cytotoxicity studies should be done at the early stages of the drug development process as a preliminary indicator of potential toxicity. In this study, plants showing MIC values less than $1 \mathrm{mg} / \mathrm{ml}$ against at least three Mycobacterium strains were investigated further for cytotoxicity against Vero monkey and bovine dermis cells. The results for cytotoxicity of selected crude extracts represented as $\mathrm{LC}_{50}$ values, and selectivity index values, which show the relationship between antimycobacterial activity and toxicity, are shown in Table 4 . Crude extracts with $\mathrm{LC}_{50}$ values $>0.1 \mathrm{mg} / \mathrm{ml}$ are considered non-cytotoxic (Kuete and Efferth, 2010).

Cytotoxicity varied in this study, and some selectivity index values were highly promising. The $\mathrm{LC}_{50}$ values of twenty-nine extracts tested ranged from $0.001-5.59 \mathrm{mg} / \mathrm{ml}$, and the selectivity index values ranged from 0.003-79.50. According to toxicity standards mentioned above, the tested extracts of G. foliosa, H. colchicifolia, H. trifoliata, P. acerosum, P. viridiflorum (bark), P. echinatus (leaf), and P. longifolia (bark) were non-cytotoxic against both Vero and bovine dermis cells with $\mathrm{LC}_{50}$ values ranging from 0.12 to $>1 \mathrm{mg} / \mathrm{ml}$, and the highest selectivity index value of 79.50 was demonstrated by $P$. acerosum root water extract. A high selectivity index value marks a large safety margin between the concentration of the test sample that is able to inhibit the growth of Mycobacterium strains and the concentration that is toxic to BD and Vero cells in this case. Therefore, selection of an extract with a high selectivity index value for further analysis increases the chances of producing a useful herbal medicine.

The bark acetone and hexane extracts of $P$. viridiflorum were previously reported to be nontoxic when tested against Artemia salina larval and hatching stages (Otang et al., 2013), to some extent supporting the safety of this plant part. Selectivity index values greater than 1 for $P$. acerosum (ethanol and water), H. colchicifolia (cold and hot water), H. trifoliata (ethanol, cold water and hot water) and $P$. longifolia (leaf acetone) extracts indicated a wide safety margin. This provides a measure of support for the traditional use of these plants against TB, and creates an urgent need for identification of safe antimycobacterial compounds from them. Lack of toxicity with extracts of $H$. trifoliata, P. viridiflorum (leaves) and $H$. colchicifolia 
Table 4: $\mathrm{LC}_{50}$ and selectivity index values of selected extracts against Vero monkey kidney and bovine dermis cells

\begin{tabular}{|c|c|c|c|c|c|c|c|c|c|c|c|c|c|c|c|c|c|c|c|}
\hline \multirow[t]{2}{*}{ Plant species } & \multirow[t]{2}{*}{ Ext } & \multirow{2}{*}{$\begin{array}{l}L_{50} \text { values } \\
\text { against Vero }\end{array}$} & \multicolumn{8}{|c|}{ Selectivity index values Vero } & \multirow{2}{*}{$\begin{array}{l}L^{L} C_{50} \text { values } \\
\text { against } \mathrm{BD}\end{array}$} & \multicolumn{8}{|c|}{ Selectivity index values BD } \\
\hline & & & M. sm & M. fo & M. $a u$ & $\begin{array}{l}\text { M. bo } \\
B C G\end{array}$ & M. go & M. bo & $\begin{array}{l}\text { M. } t b \\
\mathrm{Rv}\end{array}$ & $M . t b$ & & M. sm & M. fo & M. $a u$ & $\begin{array}{l}M . b o \\
B C G\end{array}$ & M. go & M. bo & $\begin{array}{l}\text { M. } t b \\
\mathrm{Rv}\end{array}$ & M. $t b$ \\
\hline G. foliosa $(\mathrm{Ba})$ & HW & $0.69 \pm 1.02$ & 0.552 & 2.23 & 1.10 & 1.10 & 2.23 & 1.10 & 2.23 & 2.23 & $0.28 \pm .0 .20$ & 0.22 & 0.90 & 0.44 & 0.44 & 0.22 & 0.44 & 0.90 & 0.90 \\
\hline \multirow[t]{3}{*}{ H. colchicifolia $(\mathrm{Bu})$} & $\begin{array}{l}\mathrm{A} \\
\mathrm{E}\end{array}$ & $\begin{array}{l}0.98 \pm 0.24 \\
0.89 \pm 0.45\end{array}$ & $\begin{array}{l}1.56 \\
0.71\end{array}$ & $\begin{array}{l}1.56 \\
0.36\end{array}$ & $\begin{array}{l}1.56 \\
1.41\end{array}$ & $\begin{array}{l}1.56 \\
1.41\end{array}$ & $\begin{array}{l}1.56 \\
1.41\end{array}$ & $\begin{array}{l}3.16 \\
1.41\end{array}$ & $\begin{array}{l}3.16 \\
2.87\end{array}$ & $\begin{array}{l}1.56 \\
2.87\end{array}$ & $\begin{array}{l}0.14 \pm 0.07 \\
0.19 \pm 1.04\end{array}$ & $\begin{array}{l}0.22 \\
0.15\end{array}$ & $\begin{array}{l}0.22 \\
0.076\end{array}$ & $\begin{array}{l}0.22 \\
0.30\end{array}$ & $\begin{array}{l}0.22 \\
0.30\end{array}$ & $\begin{array}{l}0.22 \\
0.30\end{array}$ & $\begin{array}{l}0.45 \\
0.30\end{array}$ & $\begin{array}{l}0.45 \\
0.61\end{array}$ & $\begin{array}{l}0.22 \\
0.61\end{array}$ \\
\hline & $\mathrm{W}$ & $2.48 \pm 0.02$ & 3.94 & 3.94 & 3.94 & 3.94 & 3.94 & 3.94 & 8.00 & 15.50 & $1.36 \pm 0.54$ & 0.63 & 2.16 & 2.16 & 4.39 & 4.39 & 2.16 & 4.39 & 8.50 \\
\hline & HW & $0.39 \pm 0.44$ & 1.25 & 2.50 & 0.62 & 1.25 & 1.25 & 2.43 & 1.26 & 1.26 & $0.36 \pm 0.27$ & 1.16 & 4.50 & 0.57 & 1.16 & 1.16 & 2.25 & 1.16 & 1.16 \\
\hline \multirow[t]{3}{*}{ H. trifoliata $(\mathrm{L})$} & $\mathrm{E}$ & $5.59 \pm 0.17$ & 8.94 & 17.88 & 8.94 & 35.83 & 35.83 & 34.94 & 69.88 & 69.88 & $1.43 \pm 0.98$ & 2.27 & 4.61 & 2.27 & 17.88 & 17.88 & 8.94 & 17.88 & 17.88 \\
\hline & $\mathrm{W}$ & $3.68 \pm 1.06$ & 5.84 & 5.84 & 5.84 & 5.84 & 5.84 & 11.87 & 23.00 & 23.00 & $0.89 \pm 0.37$ & 1.41 & 1.41 & 1.41 & 1.41 & 1.41 & 2.87 & 5.56 & 5.56 \\
\hline & $\mathrm{Hw}$ & $3.22 \pm 1.28$ & 5.10 & 20.58 & 5.10 & 1.28 & 5.10 & 5.11 & 20.13 & 10.39 & $1.33 \pm 0.54$ & 2.11 & 16.63 & 2.11 & 0.53 & 2.11 & 2.11 & 8.31 & 4.29 \\
\hline \multirow[t]{3}{*}{ P. acerosum $(\mathrm{L})$} & A & $0.59 \pm 0.82$ & 0.94 & 0.94 & 0.94 & 0.94 & 3.68 & 0.94 & 1.90 & 0.94 & $0.25 \pm 0.48$ & 0.81 & 0.81 & 0.81 & 0.81 & 1.56 & 0.40 & 0.81 & 0.40 \\
\hline & $\mathrm{E}$ & $0.28 \pm 0.78$ & 14.00 & 1.75 & 1.75 & 14.00 & 1.75 & 14.00 & 1.75 & 1.75 & $0.46 \pm 1.06$ & 23.00 & 2.88 & 2.88 & 23.00 & 2.88 & 23.00 & 2.88 & 2.88 \\
\hline & $\mathrm{W}$ & $0.99 \pm 0.26$ & 16.19 & 12.38 & 12.38 & 49.50 & 6.19 & 24.75 & 12.38 & 12.38 & $0.87 \pm 1.08$ & 5.44 & 10.88 & 10.88 & 43.50 & 5.44 & 21.75 & 10.88 & 10.88 \\
\hline \multirow[t]{2}{*}{ P. $\operatorname{acerosum}(\mathrm{R})$} & A & $0.38 \pm 0.45$ & 2.38 & 2.38 & 4.75 & 2.38 & 1.23 & 1.23 & 1.23 & 2.38 & $0.12 \pm 1.18$ & 0.75 & 0.75 & 1.50 & 0.75 & 0.39 & 0.39 & 0.39 & 0.75 \\
\hline & $\mathrm{E}$ & $0.41 \pm 0.76$ & 20.50 & 1.32 & 5.13 & 0.65 & 1.32 & 2.56 & 1.32 & 1.32 & $0.24 \pm 0.37$ & 12.00 & 0.77 & 3.00 & 12.00 & 0.38 & 1.50 & 0.77 & 0.77 \\
\hline \multirow{3}{*}{ P. viridiflorum $(\mathrm{Ba})$} & $\begin{array}{l}\text { W } \\
\text { A }\end{array}$ & $\begin{array}{l}0.59 \pm 0.86 \\
0.47 \pm 0.87\end{array}$ & $\begin{array}{l}6.88 \\
0.75\end{array}$ & $\begin{array}{l}\mathbf{2 7 . 5 0} \\
0.75\end{array}$ & $\begin{array}{l}6.88 \\
0.19\end{array}$ & $\begin{array}{l}27.50 \\
0.75\end{array}$ & $\begin{array}{l}0.87 \\
0.38\end{array}$ & $\begin{array}{l}\mathbf{1 4 . 7 5} \\
0.74\end{array}$ & $\begin{array}{l}\mathbf{1 4 . 7 5} \\
0.19\end{array}$ & $\begin{array}{l}\mathbf{1 4 . 7 5} \\
0.19\end{array}$ & $\begin{array}{l}1.59 \pm 0.50 \\
0.37 \pm 0.67\end{array}$ & $\begin{array}{l}\mathbf{1 9 . 8 8} \\
0.58\end{array}$ & $\begin{array}{l}\text { 79.50 } \\
0.58\end{array}$ & $\begin{array}{l}\mathbf{1 9 . 8 8} \\
0.15\end{array}$ & $\begin{array}{l}\mathbf{7 9 . 5 0} \\
0.58\end{array}$ & $\begin{array}{l}2.52 \\
0.30\end{array}$ & $\begin{array}{l}\mathbf{3 9 . 7 5} \\
0.59\end{array}$ & $\begin{array}{l}\mathbf{3 9 . 7 5} \\
0.15\end{array}$ & $\begin{array}{l}\mathbf{3 9 . 7 5} \\
0.15\end{array}$ \\
\hline & $\mathrm{E}$ & $0.91 \pm 1.28$ & 0.63 & 0.31 & 2.50 & 0.63 & 1.25 & 1.44 & 0.73 & 0.73 & $1.41 \pm 0.08$ & 2.24 & 4.55 & 2.50 & 2.24 & 1.13 & 2.24 & 1.13 & 1.13 \\
\hline & $\mathrm{W}$ & $1.44 \pm 1.80$ & 2.29 & 2.29 & 2.29 & 2.29 & 1.15 & 2.29 & 1.15 & 1.15 & $0.20 \pm 1.02$ & 0.32 & 0.32 & 0.32 & 0.32 & 0.16 & 0.32 & 0.16 & 0.16 \\
\hline \multirow[t]{2}{*}{ P. viridiflorum $(\mathrm{L})$} & A & $0.96 \pm 0.82$ & 1.52 & 0.38 & 0.77 & 3.10 & 3.10 & 6.00 & 3.10 & 3.10 & $0.04 \pm 1.22$ & 0.06 & 0.02 & 0.03 & 0.13 & 0.13 & 0.25 & 0.13 & 0.13 \\
\hline & $\mathrm{E}$ & $0.95 \pm 1.37$ & 0.38 & 1.51 & 0.38 & 3.06 & 3.06 & 1.51 & 0.76 & 0.38 & $0.08 \pm 0.37$ & 0.03 & 0.13 & 0.06 & 0.26 & 0.26 & 0.13 & 0.06 & 0.03 \\
\hline \multirow[t]{3}{*}{ P. echinatus $(\mathrm{L})$} & A & $0.18 \pm 0.58$ & 0.29 & 0.29 & 0.14 & 0.29 & 0.29 & 0.29 & 0.58 & 0.58 & $1.12 \pm 1.48$ & 1.78 & 1.78 & 0.90 & 1.78 & 1.78 & 1.78 & 3.61 & 3.61 \\
\hline & $\mathrm{E}$ & $0.24 \pm 0.11$ & 0.77 & 0.77 & 0.38 & 0.38 & 0.38 & 0.38 & 1.50 & 1.50 & $0.14 \pm 0.37$ & 0.45 & 0.45 & 0.22 & 0.22 & 0.22 & 0.22 & 0.88 & 0.88 \\
\hline & $\mathrm{W}$ & $0.46 \pm 0.18$ & 0.73 & 0.37 & 0.37 & 0.73 & 0.73 & 1.48 & 0.37 & 0.73 & $0.30 \pm 1.08$ & 0.48 & 0.24 & 0.24 & 0.48 & 0.48 & 0.97 & 0.24 & 0.48 \\
\hline \multirow[t]{3}{*}{ P. echinatus $(\mathrm{Ba})$} & A & $0.001 \pm 0.24$ & 0.003 & 0.003 & 0.002 & 0.003 & 0.002 & 0.01 & 0.01 & 0.00 & $0.95 \pm 0.26$ & 1.51 & 1.51 & 0.76 & 1.51 & 1.51 & 5.93 & 5.93 & 3.06 \\
\hline & $\mathrm{E}$ & $0.34 \pm 0.40$ & 1.10 & 1.10 & 0.54 & 0.54 & 0.54 & 1.10 & 1.10 & 0.54 & $0.06 \pm 0.18$ & 0.19 & 0.19 & 0.10 & 0.10 & 0.10 & 0.19 & 0.19 & 0.10 \\
\hline & $\mathrm{Hw}$ & $0.50 \pm 0.11$ & 0.79 & 0.79 & 1.61 & 0.79 & 0.79 & 0.79 & 0.40 & 1.61 & $0.01 \pm 1.02$ & 0.02 & 0.02 & 0.03 & 0.03 & 0.02 & 0.02 & 0.01 & 0.03 \\
\hline \multirow[t]{3}{*}{ P. longifolia $(\mathrm{L})$} & A & $0.87 \pm 0.37$ & 10.88 & 5.44 & 5.44 & 10.88 & 5.44 & 5.43 & 2.81 & 5.43 & $0.34 \pm 0.32$ & 4.25 & 2.13 & 2.13 & 4.25 & 2.13 & 2.13 & 1.10 & 2.13 \\
\hline & $\mathrm{E}$ & $0.04 \pm 1.08$ & 0.13 & 0.13 & 0.13 & 0.25 & 0.03 & 0.06 & 0.03 & 0.03 & $1.18 \pm 0.13$ & 3.80 & 3.80 & 3.80 & 7.38 & 0.94 & 1.87 & 0.94 & 0.94 \\
\hline & HW & $0.02 \pm 1.02$ & 0.03 & 0.03 & 0.06 & 0.06 & 0.03 & 0.06 & 0.13 & 0.06 & $0.008 \pm 0.18$ & 0.01 & 0.01 & 0.03 & 0.03 & 0.01 & 0.03 & 0.05 & 0.03 \\
\hline P. longifolia $(\mathrm{Ba})$ & HW & $0.23 \pm 0.40$ & 0.09 & 1.44 & 0.37 & 0.37 & 0.18 & 0.74 & 1.44 & 1.44 & $0.86 \pm 1.08$ & 0.34 & 5.37 & 1.37 & 1.37 & 0.69 & 2.77 & 5.38 & 5.38 \\
\hline Doxorubicin & & $0.007 \pm 0.50$ & & & & & & & & & $0.23 \pm 0.07$ & & & & & & & & \\
\hline
\end{tabular}

$\mathrm{Ba}=$ bark, $\mathrm{Bu}=$ bulb, $\mathrm{L}=$ leaf, $\mathrm{R}=$ root, $\mathrm{BD}=$ Bovine dermis cells, Vero=Vero monkey kidney cells $\mathrm{LC}_{50}=$ the lethal concentration at which $50 \%$ at which cells are killed, $M$. sm= Mycobacterium smegmatis, M. fo= Mycobacterium fortuitum, M. au= Mycobacterium aurum, M. bo $\mathrm{BCG}=$ Mycobacterium bovis $\mathrm{BCG}, M$. go= Mycobacterium gordonae, $M$. tb $\mathrm{Rv}=$ Mycobacterium tuberculosis $\mathrm{H} 37 \mathrm{RV}$, M. tb= Mycobacterium tuberculosis, M. bo= Mycobacterium bovis G. foliosa= Gerrardina foliosa, H. trifoliata= Heteromorpha trifoliata, H. colchicifolia $=$ Hypoxis colchicifolia, $P$. acerosum $=$ Phymaspermum acerosum, $P$. viridiflorum= Pittosporum viridiflorum, P. longifolia= Protorhus longifolia, P. echinatus= Pterocelastrus echinatus. Values in bold represent excellent selectivity index values (>10) 
towards Vero cells confirmed previous cytotoxicity findings by Adamu et al. (2013) and Verschaeve et al. (2013). Although non-cytotoxic, the selectivity index values of some of the extracts were lower than 1; G. foliosa (bark hot water), P. viridiflorum (bark acetone and water), H. colchicifolia (bulb acetone and ethanol), and P. echinatus (leaf ethanol and water) towards either both cells tested or one of them, suggesting that these extracts might be unsafe for use. The leaf acetone extract of $P$. longifolia was reported previously by KabongoKayoka et al. (2016) to have no toxicity at the highest concentration tested towards Vero, C3A and RAW 264.7 cells with $\mathrm{LC}_{50}$ values ranging from $0.62->1 \mathrm{mg} / \mathrm{ml}$ supporting the current safety findings of this plant extract. Furthermore, the chloroform leaf extract of $P$. longifolia was reported to be non-cytotoxic against equine erythrocytes, and Vero cells in previous research by Mosa et al. (2011). For P. longifolia, the bark ethanol extract showed selective toxicity towards Vero cells $\left(\mathrm{LC}_{50}=0.04\right)$, whereas the water extract was slightly toxic against both Vero and bovine dermis cells with $\mathrm{LC}_{50}$ values of 0.06 and $0.01 \mathrm{mg} / \mathrm{ml}$, respectively. These plant extracts should be used with caution in traditional anti-TB therapy. On a positive note, two triterpene lactones isolated from the bark of $P$. longifolia tested against human embryonic kidney and human hepatocellular carcinoma were reported to be insignificantly cytotoxic (Mosa et al. 2011), suggesting the safety of some of the constituents of this plant.

P. echinatus bark acetone (against Vero cells) and P. longifolia hot water (against bovine dermis cells) extracts were highly toxic with $\mathrm{LC}_{50}$ values of 0.001 and $0.008 \mathrm{mg} / \mathrm{ml} \mathrm{respec-}$ tively, and these two extracts displayed more toxicity towards the cells than antimycobacterial activity, as their selectivity index values were less than 1, ranging from 0.002-0.03. The bark ethanol and hot water extracts of $P$. echinatus also showed differential toxicity towards bovine dermis cells with $\mathrm{LC}_{50}$ values of 0.06 and $0.01 \mathrm{mg} / \mathrm{ml}$, respectively. Although the leaf acetone extract of $P$. viridiflorum was previously reported by Adamu et al. (2013) to have no cytotoxicity against Vero cells, in the current study the same extract and the ethanol extract was toxic to bovine dermis cells with $\mathrm{LC}_{50}$ values of 0.04 and $0.08 \mathrm{mg} / \mathrm{ml}$, respectively. Additionally, the acetone, hexane, methanol, and water extracts from $P$. viridiflorum leaves showed cytotoxicity against the Chang liver cell line in previous studies by Seo et al. (2002), Muthaura et al. (2007) and Otang et al. (2014). The cytotoxicity results observed on bark $P$. echinatus (acetone), P. longifolia (hot water and ethanol) extracts suggests that they might be unsafe for traditional use against $\mathrm{TB}$, however more in depth cytotoxicity research on these 
extracts which should include determining their in vivo cytotoxicity is required as they might respond differently.

\subsection{Genotoxicity}

Evaluation of the mutagenic effects of medicinal plants is highly recommended for detecting potential genotoxins, and the Salmonella based Ames test is used primarily to determine safety of test samples. The Salmonella typhimurium tester strains TA98 and TA100 are recommended for general genotoxicity testing as they highlight frame-shift and base-pair substitution gene mutations, respectively. In total, twenty-nine extracts were selected for the genotoxicity study, and the results are shown in Table 5. To say that an extract is genotoxic, the number of revertant colonies should be more than twice that of the negative control and a clear dose-dependent response should be observed for the various concentrations tested (Maron and Ames, 1983). Out of the extracts tested, almost all of them were negative in the Ames test with the exception of $P$. viridiflorum bark water and $H$. trifoliata leaf ethanol extracts that showed clear mutagenicity with numbers of revertant colonies greater than twice that of the negative controls for the $5 \mathrm{mg} / \mathrm{ml}$, the highest concentration tested, however decreasing with decreasing concentrations of extracts. The extracts of P. acerosum (leaf acetone), and P.viridiflorum (bark acetone and ethanol), although not toxic against S. typhimurium TA98, showed a dose-dependent response against S. typhimurium TA100. According to our knowledge, although $P$. viridiflorum has been tested for toxicity both in in vitro and in vivo studies, this is the first report of the genotoxicity testing of this plant (Madikizela and McGaw, 2017). The observed lack of genotoxicity of water extracts of $H$. colchicifolia and $H$. trifoliata (against TA98) confirmed previous findings (Elgorashi et al., 2003; Verschaeve and Van Staden, 2008; Verschaeve et al., 2013) when tested against one strain. However, H. trifoliata ethanol extract showed genotoxicity against TA100 in the current study. Therefore, the use of $P$. viridiflorum should be treated with caution and rigorous toxicological studies are necessary. For more in depth genotoxicity investigations on these plants, subsequent tests should be conducted, and they should include metabolic activation as well as other strains such as TA97, TA1535, TA102 and TA104.

\section{Conclusions}

This study reported for the first time the antimycobacterial potential of Gerrardina foliosa, Haemanthus albiflos, Heteromorpha trifoliata, Hypoxis colchicifolia, Pachycarpus concolor, Phymaspermum acerosum, Pittosporum viridiflorum, Protorhus longifolia (bark), Pterocelas- 
Table 5: Genotoxicity of selected extracts against Salmonella typhimurium strains (TA98 and TA100) presented as mean \pm standard error

\begin{tabular}{|c|c|c|c|c|c|c|c|}
\hline \multirow[t]{5}{*}{ Plant species } & \multirow[t]{5}{*}{ Extract } & \multicolumn{6}{|c|}{ Salmonella typhimurium strain } \\
\hline & & \multicolumn{3}{|c|}{ TA 98} & \multicolumn{3}{|c|}{ TA 100} \\
\hline & & \multicolumn{6}{|c|}{ Concentrations $(\mathrm{mg} / \mathrm{ml})$} \\
\hline & & $5 \mathrm{mg} / \mathrm{ml}$ & $0.5 \mathrm{mg} / \mathrm{ml}$ & $0.05 \mathrm{mg} / \mathrm{ml}$ & $5 \mathrm{mg} / \mathrm{ml}$ & $0.5 \mathrm{mg} / \mathrm{ml}$ & $0.05 \mathrm{mg} / \mathrm{ml}$ \\
\hline & & \multicolumn{6}{|c|}{ Number of revertant colonies per concentration } \\
\hline G. foliosa (bark) & Hot water & $35.00 \pm 0.53$ & $31.00 \pm 1.53$ & $37.00 \pm 1.67$ & $228.50 \pm 1.50$ & $211.33 \pm 1.09$ & $227.00 \pm 1.000$ \\
\hline \multirow[t]{4}{*}{ H. colchicifolia (bulb) } & Acetone & $29.67 \pm 0.33$ & $30.33 \pm 0.33$ & $32.33 \pm 0.33$ & $231.00 \pm 1.00$ & $233.00 \pm 0.58$ & $243.00 \pm 0.58$ \\
\hline & Ethanol & $33.33 \pm 1.13$ & $29.33 \pm 0.67$ & $27.67 \pm 0.67$ & $319.00 \pm 1.00$ & $318.33 \pm 1.90$ & $251.00 \pm 0.58$ \\
\hline & Water & $35.33 \pm 0.63$ & $31.33 \pm 0.66$ & $29.33 \pm 0.33$ & $243.00 \pm 1.53$ & $246.00 \pm 0.58$ & $246.67 \pm 0.33$ \\
\hline & Hot water & $33.33 \pm 0.33$ & $29.33 \pm 0.67$ & $27.67 \pm 0.67$ & $335.00 \pm 1.52$ & $306.33 \pm 1.49$ & $310.67 \pm 0.88$ \\
\hline \multirow[t]{3}{*}{ H. trifoliata (leaf) } & Ethanol & $32.67 \pm 0.88$ & $36.33 \pm 0.67$ & $30.67 \pm 0.33$ & $458.67 \pm 1.00$ & $202.33 \pm 0.33$ & $260.67 \pm 0.67$ \\
\hline & Water & $34.67 \pm 0.43$ & $33.33 \pm 0.03$ & $35.33 \pm 0.18$ & $257.67 \pm 0.33$ & $256.00 \pm 0.58$ & $247.33 \pm 1.33$ \\
\hline & Hot water & $30.33 \pm 0.64$ & $31.33 \pm 1.63$ & $39.33 \pm 0.33$ & $293.00 \pm 0.33$ & $296.00 \pm 0.58$ & $296.67 \pm 0.33$ \\
\hline \multirow{3}{*}{ P. acerosum (leaf) } & Acetone & $32.00 \pm 1.11$ & $39.33 \pm 1.33$ & $30.33 \pm 0.88$ & $255.67 \pm 1.45$ & $214.33 \pm 2.66$ & $209.33 \pm 3.33$ \\
\hline & Ethanol & $38.33 \pm 0.67$ & $37.000 \pm 1.00$ & $35.67 \pm 0.88$ & $258.33 \pm 2.67$ & $231.67 \pm 3.28$ & $224.00 \pm 3.00$ \\
\hline & Water & $38.67 \pm 0.33$ & $28.00 \pm 1.15$ & $32.00 \pm 0.58$ & $232.33 \pm 1.33$ & $206.00 \pm 1.00$ & $199.67 \pm 2.67$ \\
\hline \multirow[t]{3}{*}{ P. acerosum (root) } & Acetone & $45.00 \pm 1.67$ & $31.00 \pm 1.53$ & $37.00 \pm 2.08$ & $269.67 \pm 1.67$ & $245.00 \pm 2.00$ & $223.00 \pm 2.52$ \\
\hline & Ethanol & $41.67 \pm 1.88$ & $42.33 \pm 1.33$ & $40.21 \pm 1.36$ & $259.67 \pm 0.66$ & $236.67 \pm 1.33$ & $219.67 \pm 0.33$ \\
\hline & Root water & $30.00 \pm 0.50$ & $32.00 \pm 0.00$ & $31.67 \pm 0.33$ & $214.67 \pm 0.67$ & $267.33 \pm 1.33$ & $190.33 \pm 2.33$ \\
\hline \multirow[t]{3}{*}{ P. viridiflorum (bark) } & Acetone & $36.00 \pm 1.00$ & $30.67 \pm 0.88$ & $36.00 \pm 1.73$ & $323.67 \pm 1.48$ & $295.00 \pm 0.00$ & $236.00 \pm 0.00$ \\
\hline & Ethanol & $36.33 \pm 0.88$ & $31.33 \pm 1.33$ & $35.00 \pm 0.00$ & $379.67 \pm 1.67$ & $309.33 \pm 1.33$ & $320.33 \pm 1.12$ \\
\hline & Water & $64.33 \pm 0.33$ & $34.67 \pm 0.33$ & $23.00 \pm 0.00$ & $817.00 \pm 000$ & $390.33 \pm 0.34$ & $130.33 \pm 1.45$ \\
\hline \multirow[t]{2}{*}{ P. viridiflorum (leaf) } & Acetone & $33.33 \pm 0.33$ & $39.00 \pm 1.00$ & $32.33 \pm 0.33$ & $272.33 \pm 0.67$ & $236.00 \pm 1.00$ & $326.33 \pm 1.83$ \\
\hline & Ethanol & $35.33 \pm 0.63$ & $37.00 \pm 0.66$ & $34.33 \pm 0.30$ & $260.33 \pm 0.42$ & $226.00 \pm 0.30$ & $220.03 \pm 1.83$ \\
\hline \multirow[t]{3}{*}{ P. echinatus (bark) } & Acetone & $36.67 \pm 0.33$ & $36.00 \pm 0.00$ & $30.00 \pm 0.00$ & $229.33 \pm 0.88$ & $243.00 \pm 0.00$ & $249.00 \pm 0.58$ \\
\hline & Ethanol & $39.67 \pm 0.33$ & $35.33 \pm 0.33$ & $37.33 \pm 0.33$ & $257.00 \pm 0.58$ & $235.67 \pm 0.88$ & $233.33 \pm 0.33$ \\
\hline & Hot water & $32.17 \pm 1.03$ & $33.03 \pm 1.04$ & $27.23 \pm 1.67$ & $200.08 \pm 0.58$ & $215.08 \pm 0.88$ & $210.23 \pm 0.33$ \\
\hline \multirow{3}{*}{ P. echinatus (leaf) } & Acetone & $35.33 \pm 0.32$ & $32.67 \pm 0.30$ & $35.33 \pm 0.67$ & $284.33 \pm 0.33$ & $207.33 \pm 0.18$ & $244.00 \pm 0.06$ \\
\hline & Ethanol & $38.33 \pm 0.32$ & $34.67 \pm 0.30$ & $36.33 \pm 0.67$ & $284.33 \pm 0.33$ & $207.33 \pm 0.18$ & $244.00 \pm 0.06$ \\
\hline & Water & $35.00 \pm 1.33$ & $31.00 \pm 0.53$ & $27.00 \pm 1.08$ & $245.00 \pm 2.00$ & $154.67 \pm 1.17$ & $174.00 \pm 1.00$ \\
\hline \multirow{3}{*}{ P. longifolia (leaf) } & Acetone & $33.00 \pm 1.33$ & $37.00 \pm 1.08$ & $35.33 \pm 0.36$ & $199.67 \pm 1.86$ & $211.33 \pm 1.86$ & $217.00 \pm 1.00$ \\
\hline & Ethanol & $38.00 \pm 0.63$ & $35.00 \pm 1.67$ & $32.00 \pm 1.00$ & $235.50 \pm 1.03$ & $203.50 \pm 1.07$ & $200.00 \pm 1.08$ \\
\hline & Hot water & $36.10 \pm 0.33$ & $30.00 \pm 0.08$ & $35.37 \pm 1.36$ & $209.6667 \pm 1.36$ & $192.000 \pm 1.51$ & $196.000 \pm 0.00$ \\
\hline P. longifolia (bark) & Hot water & $33.27 \pm 0.63$ & $34.08 \pm 1.10$ & $30.63 \pm 1.36$ & $197.000 \pm 1.00$ & $197.000 \pm 1.00$ & $164.000 \pm 2.00$ \\
\hline $4-\mathrm{NQO}$ & $235.00 \pm 0.58$ & & & & $889.67 \pm 0.33$ & & \\
\hline $10 \%$ DMSO & $25.00 \pm 0.57$ & & & & $219.33 \pm 1.45$ & & \\
\hline Water & $30.67 \pm 1.33$ & & & & $220.67 \pm 1.20$ & & \\
\hline
\end{tabular}

4-NQO= 4-nitroquinoline-1-oxide, DMSO= dimethyl sulfoxide, G. foliosa= Gerrardina foliosa, . trifoliata= Heteromorpha trifoliata, H. colchicifolia $=$ Hypoxis colchicifolia, $P$. acerosum=

Phymaspermum acerosum, $P$. viridiflorum= Pittosporum viridiflorum, $P$. longifolia $=$ Protorhus longifolia, . echinatus= Pterocelastrus echinatus 
trus echinatus, and Talinum caffrum. Noteworthy antimycobacterial activity exhibited by the water extracts of $H$. colchicifolia, H. trifoliata and P. acerosum provided support for the traditional use of these plant species against TB in the eastern region of OR Tambo district. The antimycobacterial and safety findings demonstrated by crude extracts of some of the plants; G. foliosa, H. colchicifolia, H. trifoliata, P. acerosum, P. echinatus (leaf), and P. longifolia (bark), provide strong motivation for further investigation to determine if they could be sources of antimycobacterial drugs. However, cytotoxicity of extracts from bark of P. echinatus (acetone) and P. longifolia (ethanol and hot water) as well as genotoxicity of $P$. viridiflorum bark water and $H$. trifoliata leaf ethanol extracts suggest that they should be used with caution in traditional medicine. The findings of this study support suggesting the use of leaves of $P$. viridiflorum, $P$. longifolia, $P$. echinatus, and Haemanthus albiflos in traditional TB therapy as the leaf extracts also showed comparable antimycobacterial activity to the other more vulnerable parts of the plants, such as bulbs. Further studies should be aimed at determining the antimycobacterial activity against drug resistant Mycobacterium strains, the effect of combining active crude extracts with currently used anti-TB drugs, determining the intracellular antimycobacterial activity of active crude extracts in macrophages, and their effect on cytokine production.

\section{List of Abbreviations}

MTT = 3-(4,5-dimethylthiazol-2-yl)-2,5-diphenyltetrazolium bromide, 4-NQO = 4nitroquinoline-1-oxide, ARVs = Antiretroviral drugs, BCG = Bacille Calmette-Guerin, DMSO = Dimethylsulfoxide, FCS $=$ Foetal calf serum, FDA $=$ Food and Drug Administration, HIV = Human Immunodeficiency Virus, INT $=p$-iodonitro-tetrazolium chloride, $\mathrm{LC}_{50}=$ Lethal concentration at which $50 \%$ at which cells are killed, MDR $=$ Multi drug resistant, $\mathrm{MEM}=$ Minimal essential medium, $\mathrm{MIC}=$ Minimum inhibitory concentration, $\mathrm{PBS}=$ Phosphate buffered saline, $\mathrm{TB}=$ Tuberculosis, TDR $=$ Totally drug resistant, $\mathrm{WHO}=$ World Health Organisation, XDR = Extensively drug resistant

\section{Acknowledgements}

The authors would like to thank the South African Medical Research Council (SIR funding to LJM) and National Research Foundation (NRF), South Africa for providing financial support. Annette Venter and Sanah Nkadimeng are thanked for providing bovine dermis 
cells. Alison Young (University of KwaZulu-Natal), Jason Sampson (University of Pretoria) are thanked for assisting with plant material collection.

\section{Conflict of interest}

The authors declare no conflict of interest.

\section{Author contribution list}

BM conceptualised the study, conducted the research and wrote the manuscript. LM supervised the work, provided funding, edited and submitted the manuscript.

\section{References}

Adamu, M., Naidoo, V., Eloff, J.N., 2013. Efficacy and toxicity of thirteen plant leaf acetone extracts used in ethnoveterinary medicine in South Africa on egg hatching and larval development of Haemonchus contortus. BMC Veterinary Research 9, doi: 10.1186/17466148-9-38.

Altaf, M., Miller, C.H., Bellows, D.S., O'Toole, R., 2010. Evaluation of the Mycobacterium smegmatis and BCG models for the discovery of Mycobacterium tuberculosis inhibitors. Tuberculosis 90, 333-337.

Aremu, A.O., Ndhlala, A.R., Fawole, O.A., Light, M.E., Finnie, J.F., van Staden, J., 2010. In vitro pharmacological evaluation and phenolic content of ten South African medicinal plants used as anthelmintics. South African Journal of Botany 76,558-566.

Aro, A.O., Dzoyem, J.P., Hlokwe, T.M., Madoroba, E., Eloff, J.N., McGaw, L.J. 2015. Some South African Rubiaceae tree leaf extracts have antimycobacterial activity against pathogenic and non-pathogenic Mycobacterium species. Phytotherapy Research 29, 1004-1010. 
Bassey, K., Viljoen, A., Combrinck, S., Choi, Y.H., 2014. New phytochemicals from the corms of medicinally important South African Hypoxis species. Phytochemistry Letters 10, doi:10.1016/j.phytol.2014.09.014.

Baudoin, F., Tillequin, F., Koch, M., 1994. Albiflomanthine: A crinane alkaloid from Haemanthus albiflos (Jacq.). Heterocycles 38, 965-970.

Cantrell, C.L., Fischer, N.H., Urbatsch, L., McGuire, M.S., Franzblau, S.G., 1998. Antimycobacterial crude plant extracts from South, Central, and North America. Phytomedicine 5, $137-145$.

Clarkson, C., Maharaj, V.J., Crouch, N.R., Grace, O.M., Pillay, P., Matsabisa, M.G., Bhagwandin, N., Smith, P.J., Folb, P.I., 2004. In vitro antiplasmodial activity of medicinal plants native to or naturalised in South Africa. Journal of Ethnopharmacology 92, 177-191.

Cock, I.E., van Vuuren, S.F., 2014. Anti-proteus activity of some South African medicinal plants: their potential for the prevention of rheumatoid arthritis. Inflammopharmacology 22, 23-36.

Crouch, N.R., Pohl, T.L., Mulholland, D.A., Ndlovu, E., 2005. Alkaloids from three ethnomedicinal Haemanthus species: H. albiflos, H. deformis and H. pauculifolius (Amaryllidaceae). South African Journal of Botany 71, 49-52.

Elgorashi, E.E., Taylor, J.L.S., Maes, A., Van Staden, J., De Kimpe, N., Verschaeve, L., 2003. Screening of medicinal plants used in South African traditional medicine for genotoxicity effects. Toxicology Letters 143, 195-207.

Eloff, J.N., 1998. A sensitive and quick microplate method to determine the minimal inhibitory concentration of plant extracts for bacteria. Planta Medica 64, 711-713.

Famewo, E.B., Clarke, A.N., Afolayan, A.J., 2017. Ethno-medicinal documentation of polyherbal medicines used for treatment of tuberculosis in Amathole District Municipality of the Eastern Cape, South Africa. Pharmaceutical Biology 55, 696-700. 
Fyhrquist, P., Laakso, I., Garcia-Marco, S., Julkunen-Tiitto, R., Hiltunen, R., 2014. Antimycobacterial activity of ellagitannin and ellagic acid derivate rich crude extracts and fractions of five selected species of Terminalia used for treatment of infectious diseases in African traditional medicine. South African Journal of Botany 90, 1-16.

Green, E., Samie, A., Obi, C.L., Bessong, P.O., Ndip, R.N., 2010. Inhibitory properties of selected South African medicinal plants against Mycobacterium tuberculosis. Journal of Ethnopharmacology 130, 151-157.

Hong, C.E., Lyu, S.Y., 2011. Genotoxicity detection of five medicinal plants in Nigeria. The Journal of Toxicological Sciences 36, 87-93.

Husson, G.P., Subra, F., Lai-Kuen, R., Vilaginès, R., 1997. Antiviral activity of hydroalcoholic extract from Haemanthus albiflos on the moloney murine leukemia virus and the human immunodeficiency virus. Comptes Rendus des Seances de la Societe de Biologie et de ses Filiales 191, 473-485.

Husson, G.P., Vilagines, P., Sarrette, B., Vilagines, R., 1994. Study of antiviral action of total alkaloids from Haemanthus albiflos. Annales Pharmaceutiques Francaises 52, 311-322.

Husson, G.P., Vilaginès, P., Sarrette, B., Vilaginès, R., 1995. Use of cell culture for the research of cytotoxic and antiviral effects of a natural extract of Amaryllidaceae. Comptes Rendus des Seances de la Societe de Biologie et de ses Filiales 189, 679-692.

Jadaun, G.P.S., Agarwal, C., Sharma, H., Ahmed, Z., Upadhyay, P., Faujdar, J., Gupta, A.K., Das, R., Gupta, P., Chauhan, D.S., Sharma, V.D., Katoch, V.M., 2007. Determination of ethambutol MICs for Mycobacterium tuberculosis and Mycobacterium avium isolates by resazurin microtitre assay. Journal of Antimicrobial Chemotherapy 60, 152-155.

John, A.J., Karunakaran, V.P., Georgea, V., Pradeep, N.S., Sethuraman, M.G., 2007. Constituents and antibacterial activity of the essential oils from the leaves and fruits of Pittosporum viridulum. Journal of Essential Oil Research 19, 591-593. 
Kabongo-Kayoka, P.N., Eloff, J.N., Obi, C.L., McGaw, L.J., 2016. Antimycobacterial activity and low cytotoxicity of some African Anacardiaceae tree species. Phytotherapy Research 30, 2001-2011.

Katerere, D., Parry, O., 2000. Pharmacological actions of Heteromorpha trifoliata ("dombwe") on rat isolated muscle preparations. The Central African Journal of Medicine 46, 9-13. Kuete, V., Efferth, T., 2010. Cameroonian Medicinal Plants: Pharmacology and Derived Natural Products. Frontiers in Pharmacology 1, doi: 10.3389/fphar.2010.00123.

Luo, X. Pires, D., Ainsa, J.A., Gracia, B., Mulhovo, S., Duarte, A., Anes, E., Ferreira, M.-J., 2011. Antimycobacterial evaluation and preliminary phytochemical investigation of selected medicinal plants traditionally used in Mozambique. Journal of Ethnopharmacology 137, 114120.

Machaba, K.E., Cobongela, S.Z.Z., Mosa, R.A., Oladipupo, L.A., Djarova, T.G., Opoku, A.R., 2014. In vivo anti-hyperlipidemic activity of the triterpene from the stem bark of Protorhus longifolia (Benrh) Engl. Lipids in Health and Disease 13, 1-7.

Madikizela, B. Kambizi, L., McGaw, L.J., 2017. An ethnobotanical survey of plants used traditionally to treat tuberculosis in the eastern region of OR Tambo district, South Africa. South African Journal of Botany109, 231-236.

Madikizela, B., McGaw, L.J., 2017. Pittosporum viridiflorum Sims (Pittosporaceae): A review on a useful medicinal plant native to South Africa and tropical Africa. Journal of Ethnopharmacology 205 217-230.

Mahajan, R., 2013. Bedaquiline: First FDA-approved tuberculosis drug in 40 years. International Journal of Applied Basic Medical Research 3, 1-2.

Maharaj, R., Maharaj, V., Crouch, N.R., Bhagwandin, N., Folb, P.I., Pillay, P., Gayaram, R., 2011. Screening for adulticidal bioactivity of South African plants against Anopheles arabiensis. Malaria Journal 10, doi:10.1186/1475-2875-10-233. 
Maron, D.M., Ames, B.N., 1983. Revised methods for the Salmonella mutagenicity test. Mutatation Research 113, 173-215.

Masoko, P., Nxumalo, K.M., 2013. Validation of antimycobacterial plants used by traditional healers in three districts of the Limpopo Province (South Africa). Evidence-Based Complementary and Alternative Medicine 2013, Article ID 586247.

McGaw, L.J., Jäger, A.K., Van Staden, J., 2000. Antibacterial, anthelmintic and anti-amoebic activity in South African medicinal plants. Journal of Ethnopharmacology 72, 247-263.

McGaw, L.J., Lall, N., Meyer, J.J.M., Eloff, J.N., 2008a. The potential of South African plants against Mycobacterium infections. Journal of Ethnopharmacology 119, 482-500.

McGaw, L.J., Lall, N., Hlokwe, T.M., Michel, A.L., Meyer, J.J.M., Elolff, J.N., 2008b. Purified compounds and extracts from Euclea species with antimycobacterial activity against Mycobacterium bovis and fast-growing mycobacteria. Biological and Pharmaceutical Bulletin $31,1429-1433$.

Mdluli, K., Kaneko, T., Upton, A., 2015. The tuberculosis drug discovery and development pipeline and emerging drug targets. Cold Spring Harbor Perspectives in Medicine 5, doi: 10.1101

Molina-Salinas, G.M., Ramos-Guerra, M.C., Vargas-Villarreal, J., Mata-Cardenas, B.D., Becerril-Montes, P., Said-Fernandeza, S., 2006. Bactericidal activity of organic extracts from Flourensia cernua DC against strains of Mycobacterium tuberculosis. Archives of Medical Research 37, 45-49.

Mortelmans, K., Zeiger, K., 2000. The Ames Salmonella/Microsome mutagenicity assay. Mutatation Research 455, 29-60.

Mosa, R.A.,Oyedeji, O.A., Shode, F.O., Singh, M., Opoku, A.R., 2011. Triterpenes from the stem bark of Protorhus longifolia exhibit anti-platelet aggregation activity. African Journal of Pharmacy and Pharmacology 5, 2698-2714. 
Mosmann, T., 1983. Rapid colorimetric assay for cellular growth and survival: application to proliferation and cytotoxicity assays. Journal of Immunological Methods 65, 55-63.

Muthaura, C.N., Rukunga, G.M., Chhabra, S.C., Omar, S.A., Guantai, A.N., Gathirwa, J.W., Tolo, F.M., Mwitari, P.G., Keter, L.K., Kimani, C.W., Mungai, G.M., Njagi, E.N.M., 2007. Antimalarial activity of some plants traditionally used in the Meru district of Kenya. Phytotherapy Research 21, 860-867.

Mwangi, J.W., Achola, K.J., Lwande, W., Hassanali, A., 1994. Volatile components of Heteromorpha trifoliata (Wendl.) Eckl. and Zey [1994]. Flavour and Fragrance Journal 9, 241243.

Nguta, J.M., Appiah-Opong, R., Nyarko, A.K., Yeboah-Manu, D., Addo, P.G.A, Otchere, I., Kissi-Twuma, A., 2016. Antimycobacterial and cytotoxic activity of selected medicinal plant extracts. Journal of Ethnopharmacology 182, 10-15.

Ntuli, S.B.N., 2006. Ethnopharmacology and Phytochemistry of some Selected Medicinal Plants in KwaZulu-Natal. Msc Thesis, University of KwaZulu-Natal, South Africa.

Nyabayo, C.T., Matasyoh, J.C., Mwendia, C., 2015. In vitro assessment of pentacyclic triterpenoids from leaves of Pittosporum viridiflorum against east coast fever vector Rhipicephalus appendiculatus. American Journal of Chemistry and Application 2, 95-100.

Nyongbela, K.D., Lannang, A.M., Ayimele, G.A., Ngemenya, M.N., Bickle, Q., Efange, S., 2013. Isolation and identification of an antiparasitic triterpenoid estersaponin from the stem bark of Pittosporum mannii (Pittosporaceae). Asian Pacific Journal of Tropical Disease 3, 389-392.

Otang, W.M., Grierson, D.S., Ndip, R.N., 2012. Phytochemical studies and antioxidant activity of two South African medicinal plants traditionally used for the management of opportunistic fungal infections in HIV/AIDS patients. BMC Complementary and Alternative Medicine 12, 43. http://dx.doi.org/10.1186/1472-6882-12-43. 
Otang, W.M., Grierson, D.S., Ndip, R.N., 2013. Assessment of potential toxicity of three South African medicinal plants using the brine shrimp (Artemia salina) assay. African Journal of Natural Products Communication 10, 1311-1314.

Phungula, K.V., Marston, A., Zietsman, P.C., Bonnet, S.L., 2014. Ethnobotanical survey of plants used for the treatment of tuberculosis by traditional health healers in the Free State Province, South Africa. Planta Medica 80, DOI: 10.1055/s-0034-1395111.

Ramanandraibe, V., Rakotovao, M., Frappier, F., Martin, M.-T., 2001. 1H and 13C NMR structure determination of new sesquiterpene glycosides isolated from Pittosporum viridiflorum. Magnetic Resonance in Chemistry 39, 762-764.

Ramos, D.F., Leitão, G.G., Costa, F.D, Abreu, L., Villarreal, J.V., Leitão, S.G., Fernández, S.L.S., da Silva, P.E.A., 2008. Investigation of the antimycobacterial activity of 36 plant extracts from the Brazilian Atlantic forest. Brazilian Journal of Pharmaceutical Sciences 44, 669-674.

Recio, M.C., Just, M.J., Giner, R.M., Manez, S., Rios, J.L., Hostettmann, K., 1995. Antiinflammatory activity of saikosaponins from Heteromorpha trifoliata. Journal of Natural Products 58, 140-144.

Rìos, J.L., Recio, M.C., 2005. Medicinal plants and antimicrobial activity. Journal of Ethnopharmacology 100, 80-84.

Risa, J., Risa, A., Adsersen, A., Gauguin, B., Stafford, G.I., van Staden, J., Jäger, A.K. 2004. Screening of plants used in southern Africa for epilepsy and convulsions in the GABA-Abenzodiazepine receptor assay. Journal of Ethnopharmacology 93: 177-182.

Santin, J.R., Silveira, A., Muller, E., Claudino, V.D., Cruz, A.B., Bürger, C., de Freitas, R.A., Malheiros, A., 2011. Evaluation of the acute toxicity, genotoxicity and mutagenicity of ethanol extract of Piper aduncum. Journal of Medicinal Plants Research 5, 4475-4480. 
Semenya, S.S., Maroyi, A., 2013. Medicinal plants used for the treatment of tuberculosis by Bapedi traditional healers in three districts of the Limpopo Province, South Africa. African Journal of Traditional, Complementary and Alternative Medicine 10, 316-323.

Seo, Y., Berger, J.M., Hoch, J., Neddermann, K.M., Bursuker, I., Mamber, S.W., Kingston, D.G.I., 2002. A new triterpene saponin from Pittosporum viridiflorum from the Madagascar rainforest. Journal of Natural Products 65, 65-68.

Stavri, Gibbons, 2005. The antimycobacterial constituents of Dill (Anethum graveolens). Phytotherapy Research 19, 938-941.

Suleiman, M.M., Bagla, V., Naidoo, V., Eloff, J.N., 2010. Evaluation of selected South African plant species for antioxidant, antiplatelet, and cytotoxic activity. Pharmaceutical Biology $48,643-650$.

van Vuuren, S.F., Viljoen, A.M., 2006. The in vitro antimicrobial activity of toothbrush sticks used in Ethiopia. South African Journal of Botany 72, 646-648.

Verschaeve, L., Mertens, B., Ndhlala, A.R., Anthonissen, R., Gorissen, B., Van Staden, J., 2013. Investigation into the genotoxicity of water extracts from Hypoxis species and a commercially available Hypoxis preparation. Phytotherapy Research 27 350-356.

Verschaeve, L., Van Staden, J., 2008. Mutagenic and antimutagenic properties of extracts from South African traditional medicinal plants. Journal of Ethnopharmacology 119 575-587. Villegas, M., Vargas D., Msonthi, J.D., Marston, A., Hostettmann, K., 1988. Isolation of the antifungal compounds falcarindiol and sarisan from Heteromorpha trifoliata Planta Medica $54,36-37$.

World Health Organisation (WHO), 2017. Bending the curve-ending TB 2017 report. Regional Office for South-East Asia, India. 